\title{
A time-resolved interaction analysis of Bem1 reconstructs the flow of Cdc42 during polar growth
}

\author{
Sören Grinhagens ${ }^{1, \star}$, Alexander Dünkler ${ }^{1, \star}$, Yehui Wu ${ }^{1, \star}$, Lucia Rieger ${ }^{1, \star}$, Philipp Brenner $^{1} \mathbb{\oplus}$, Thomas Gronemeyer ${ }^{1}$, \\ Medhanie A Mulaw², Nils Johnsson ${ }^{1}$ (1)
}

\begin{abstract}
Cdc42 organizes cellular polarity and directs the formation of cellular structures in many organisms. By locating Cdc24, the source of active Cdc42, to the growing front of the yeast cell, the scaffold protein Bem1, is instrumental in shaping the cellular gradient of Cdc42. This gradient instructs bud formation, bud growth, or cytokinesis through the actions of a diverse set of effector proteins. To address how Bem1 participates in these transformations, we systematically tracked its protein interactions during one cell cycle to define the ensemble of Bem1 interaction states for each cell cycle stage. Mutants of Bem1 that interact with only a discrete subset of the interaction partners allowed to assign specific functions to different interaction states and identified the determinants for their cellular distributions. The analysis characterizes Bem1 as a cell cycle-specific shuttle that distributes active Cdc42 from its source to its effectors. It further suggests that Bem1 might convert the PAKs Cla4 and Ste20 into their active conformations.
\end{abstract}

DOI 10.26508/lsa.202000813 | Received 12 June 2020 | Revised 20 July 2020 | Accepted 21 July 2020 | Published online 31 July 2020

\section{Introduction}

Bud formation, growth, and cell separation are the visible consequences of polar cell growth in the budding yeast (Bi \& Park, 2012; Howell \& Lew, 2012). Interactions between the involved cell polarity proteins might act as switches to drive these morphological alterations. Accordingly, changes in the composition and structure of the protein interaction network should correlate with the different phases of cell growth.

Yeast cells initiate bud formation at a predetermined site, expand the bud preferentially at its tip, switch in large buds to an isotropic growth, and finally reorient the growth axis during mitosis and cell separation (Howell \& Lew, 2012). The Rho-like GTPase Cdc42 influences local cell expansion in all cell cycle phases by binding in its active, GTP-bound state to different effector proteins (Chiou et al, 2017). Cdc42 ${ }_{\text {GTP }}$ instructs the organization of the septin- and actin cytoskeleton, the spatial organization of exocytosis, mating, osmolarity sensing, and mitotic exit (Pruyne et al, 2004; Bi \& Park, 2012). Cdc24, the guanine-nucleotide-exchange factor (GEF) for Cdc42, and a variety of (GAPS) GTPase-activating protein adjust the concentration of $\mathrm{Cdc42}$ GTP at the cortex (Smith et al, 2002). The concentration of Cdc42 GTP changes over the cell cycle and peaks at the G1/S and at anaphase (Atkins et al, 2013).

Bem1 is the central scaffold for proteins that organize polarized growth in yeast (Chenevert et al, 1992; Peterson et al, 1994; Bender et al, 1996; Matsui et al, 1996). Bem1 binds Cdc24, Cdc42 GTP, and several Cdc42 GTP effector proteins (Bose et al, 2001; Irazoqui et al, 2003). The protein is part of the polarity cap during bud growth, cell separation, cell mating, and fusion and assists Cdc42 in the pheromone response-, the filamentous growth-, and the high osmolarity MAPK pathways (Lyons et al, 1996; Leberer et al, 1997; Winters \& Pryciak, 2005; Tanaka et al, 2014).

During G1, Bem1 plays a key role in polarity establishment by forming a stable zone of Cdc42 GTP at the cell cortex. Physically connecting Ccd24 to $\mathrm{CdC4} 2_{\mathrm{GTP}}$, Bem1 organizes a positive feedback where Cdc42 ${ }_{\text {GTP }}$ attracts further Cdc24 to activate even more Cdc42 (Irazoqui et al, 2003; Kozubowski et al, 2008; Woods et al, 2015; Witte et al, 2017).

Bem 1 consists of two N-terminally located (SH3) SRC homology 3 domains ( $\mathrm{SH}_{\mathrm{a}}$ and $\mathrm{SH}_{\mathrm{b}}$ ), a lipid-binding (PX) phox homology domain, and a C-terminal (PB1) Phox and Bem1 domain (PB1 ${ }_{\text {Bem1 }}$ ) (Bender et al, 1996; Matsui et al, 1996). SH3 interacts with well-characterized PxxP motifs in the p21 activated kinase (PAKs) Cla4 and Ste20, and the polarity proteins Boi1 and Boi2 (Bender et al, 1996; Bose et al, 2001; Winters \& Pryciak, 2005; Gorelik \& Davidson, 2012). SH3b harbors a C-terminal extension ( $\mathrm{Cl}$ ) that binds Cdc42 ${ }_{\text {GTP }}$ (Yamaguchi et al, 2007; Takaku et al, 2010). PB1 Bem1 $_{1}$ binds the C-terminal PB1 domain of Cdc24 with high affinity and localizes Cdc24 to sites of polar growth during all cell cycle stages (Butty et al, 2002; Woods et al, 2015; Witte et al, 2017). The mechanisms of Bem1's precisely regulated cellular distribution are, however, not fully understood (Woods et al, 2015; Meca et al, 2019).

Linking Cdc42 to Cdc24 might not suffice to explain the many functions of Bem1 during the other phases of the cell cycle (Atkins

${ }^{1}$ Department of Biology, Institute of Molecular Genetics and Cell Biology, Ulm University, Ulm, Germany ${ }^{2}$ Comprehensive Cancer Center UIm, Institute of Experimental Cancer Research, UIm University, Ulm, Germany 
et al, 2008; Kozubowski et al, 2008; Li \& Wedlich-Soldner, 2009). Instead, Bem1 was also shown to modestly stimulate Cdc24's GEF activity (Smith et al, 2013; Rapali et al, 2017). By simultaneously binding to Cla4/Ste20, active Cdc42, and Cdc24, Bem1 might also induce a negative feedback to tone down the activity of Cdc24 during later stages of the cell cycle (Gulli et al, 2000; Kozubowski et al, 2008; Kuo et al, 2014; Rapali et al, 2017).

Here, we probe the interaction network of Bem1 throughout polar growth and cytokinesis to correlate changes in composition and architecture of the network with changes in cellular morphology and the activities of its binding partners.

\section{Results}

\section{A protein interaction map of Bem1}

We searched for binding partners of Bem 1 by performing a systematic split-ubiquitin (Split-Ub) screen of Bem1- $\mathrm{C}_{\mathrm{ub}}$-RUra3 (Bem1CRU) against $548 \mathrm{Nub}_{\mathrm{ub}}$ fusion proteins known or suspected to be involved in different aspects of polarized growth in yeast (see the Materials and Methods section) (Johnsson \& Varshavsky, 1994; Hruby et al, 2011). The screen identified besides known binding partners, Bud6, Msb1, Ras1, Ras2, Rga2, Nba1, Spa2, Cdc11, Fks1, and Bem1 as novel interaction partners of Bem1 (Fig 1A). We repeated the screen with mutants of Bem1 that either carried the well-characterized W192K exchange in $\mathrm{SH}_{\mathrm{b}}\left(\mathrm{Bem}_{\mathrm{WK}_{\mathrm{K}} \mathrm{CRU}}\right.$ ) or lacked the C-terminal PB1 domain, and thus, the binding site to $\mathrm{Cdc} 24$ (Bem1 ${ }_{\triangle \mathrm{PB} 1} \mathrm{CRU}$ ) (Fig $1 \mathrm{~A}$ and $\mathrm{B}$ ). The comparison with Bem1CRU fusion revealed that Bem1 ${ }_{W K}$ lost its interactions to Boi1, Ste20, Cla4, Bud6, Nba1, and Bem1 and showed a strongly reduced binding to Boi2 but retained its interactions with Exo70, Cdc24, Cdc42, Cdc11, Rga2, Msb1, Ras2, and Ras1 (Fig 1A and B). Deleting the $\mathrm{PB} 1$ domain in $\mathrm{Bem} 1_{\mathrm{PB} 1 \Delta} \mathrm{CRU}$ removed or strongly reduced the interactions of Bem1 to $\mathrm{N}_{\mathrm{ub}}-\mathrm{Cdc} 24,-\mathrm{Cdc11}$, -Rga2, -Msb1, -Ras1, -Ras2, and -Exo70 (Fig 1A and B). Neither mutation visibly affected the interaction of Bem1 with Fks1, Cdc42, or Spa2 (Fig 1A).

\section{Dissection of the Bem1 interaction network}

The Split-Ub assay detects direct and indirect protein interactions (Hruby et al, 2011; Johnsson, 2014). SH3 b mediates the interactions between Bem1 and Boi1, Boi2 (Boi1/2), Nba1, or Bud6 (Fig 1A and B). Boi1/2 bind $\mathrm{SH}_{\mathrm{b}}$ and interact directly with Bud6 and $\mathrm{Nba} 1$ (Bender et al, 1996; Kustermann et al, 2017). To test whether Boi1/2 link Bem1 to Nba1 or Bud6, we introduced Bem1CRU together with $\mathrm{N}_{u b}$-Bud6, or $\mathrm{N}_{\mathrm{ub}}$-Nba1 in a strain that carried either a deletion of $\mathrm{BO} / 1$ or $\mathrm{BO} / 2$, or a deletion of $\mathrm{BO} 2 \mathrm{2}$ and the mutated binding site of Boi1 for Bem1 (boi2 $\Delta$ boi1 $_{\text {PXXPA}}$ ). The Split-Ub assays confirmed that the interactions between Bem1 and Bud6 or Bem1 and Nba1 clearly depend on Boi1/2 (Fig 2A). The nearly complete loss of interaction between

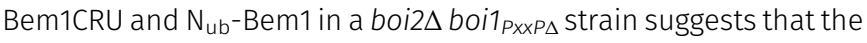
Split-Ub detected Bem1-Bem1 interaction is predominantly mediated by the multimerization of the Boi proteins (Figs $1 A$ and $B$ and 2A) (Kustermann et al, 2017). In contrast to the Nba1-Boi1/2-Bem1 or the Bem1-Boi1/2-Bem1 complex, the interaction between Bud6 and Bem1 was already lost upon deleting either BOI1 or BOI2 (Fig 2A).
The Bni1-Bud6 complex nucleates the polymerization of linear actin filaments (Graziano et al, 2011, 2013). Full activity of Bni1 requires its association with a Rho-GTPase (Evangelista et al, 1997; Dong et al, 2003). Bud6 consists of a C-terminal actin- and Bni1binding domain and an $\mathrm{N}$-terminal region of unknown function (Tu et al, 2012). Testing $\mathrm{N}_{\mathrm{ub}}$-Boi1 and $\mathrm{N}_{\mathrm{ub}}$-Boi2 against $\mathrm{CRU}$ fusions to the $\mathrm{N}$ - and $\mathrm{C}$-terminal fragments of Bud6 located the binding sites for Boi1/2 to its N-terminal 364 residues (Fig 2B). The GST fusion to this fragment precipitated Boi1- and Boi2-GFP from yeast extracts, thus providing an independent confirmation of the Split-Ub analysis and for the existence of a novel potential actin nucleation complex (Fig 2C and D) (Glomb et al, 2020).

Nba1 was reported to down-regulate the concentration of active Cdc42 during cytokinesis (Meitinger et al, 2014). Testing $\mathrm{N}$ - and C-terminal fragments of $\mathrm{N}_{\mathrm{ub}}$-Boi1/2 located the binding sites for Nba1 to the $\mathrm{SH} 3$ domains of both proteins (Fig 3A). Introducing single residue exchanges into the SH3 domains of $\mathrm{N}_{\mathrm{ub}}$-Boi1/2 (Boi1 ${ }_{W K}$, Boi1 $1_{\mathrm{PL}}$, Boi2 $\mathrm{WK}_{\mathrm{W}}$, and Boi2 $2_{\mathrm{PL}}$ ) also abolished the interactions with Nba1CRU (Fig 3B) (Larson \& Davidson, 2000). Testing a C-terminal fragment of Nba1 as $\mathrm{N}_{\mathrm{ub}}$ fusion against Boi1- and Boi2CRU restricted the binding motif for both $\mathrm{SH} 3$ domains between residues 256 and 501 of Nba1 (Fig 3B and C). This region harbors a consensus-binding motif for the $\mathrm{SH} 3$ domains of Boi1/2 (Tonikian et al, 2009). Removing this PxxP site ( $\mathrm{Nba}_{\mathrm{Pxx} \Delta}$, Fig $3 \mathrm{C}$ ) impaired the interaction between the corresponding $\mathrm{N}_{\mathrm{ub}}-\mathrm{Nba}_{\mathrm{Pxx} \Delta}$ and the $\mathrm{C}_{\mathrm{ub}}$ fusions of Boi1/2 or Bem1 (Fig 3B and C). Surface plasmon resonance spectrometry determined the $K_{D} S$ between the PxxP site (6xHIS-Nba1 $\left.1_{202-289} \mathrm{SNAP}\right)$ and $\mathrm{SH}_{\text {Boi1 }}$ and $\mathrm{SH}_{\text {Boi2 }}$ to $~ 0.74 \mu \mathrm{M}(\mathrm{n}=3)$ and $1.97 \mu \mathrm{M}(\mathrm{n}=2)$, respectively (Fig 3D).

Nba1 is attached to the bud neck through a direct interaction with Gps1 (Meitinger et al, 2014). Split-Ub analysis reproduced the interactions of GPs1CRU with the $\mathrm{N}_{\mathrm{ub}}$-fusions of $\mathrm{Nba1}$, and $\mathrm{Nba}_{\text {PXxP }}$, and revealed novel interactions between GPs1CRU and $\mathrm{N}_{\mathrm{ub}}$-Boi1/2 (Fig 3B). Mutations in the SH3 domains of $\mathrm{N}_{\mathrm{ub}}$-Boi1/2 abolished their interactions with Gps1CRU (Fig 3B). A C-terminal fragment of Gps1 still interacted as CRU fusion with $\mathrm{N}_{\mathrm{ub}}$-Nba1 and $\mathrm{N}_{\mathrm{ub}}$-Boi1 (Fig 3E). The interaction between $\mathrm{Gps}_{537-758} \mathrm{CRU}$ and $\mathrm{N}_{\mathrm{ub}}{ }^{-}$ Boi1 was lost in an nba1s-strain. The experiments support the existence of a protein complex connecting Bem1 with Gps1 through Boi1/2 and Nba1 (Fig 3E and F).

The interaction signal between Bem1CRU and $\mathrm{N}_{\mathrm{ub}}$ - $\mathrm{Cdc} 11$ was lost upon removal of $\mathrm{PB}_{\mathrm{Bem} 1}$ (Fig 1). Cdc11 interacts directly with $\mathrm{Cdc} 24$ (Chollet et al, 2020). We conclude that the interaction between Cdc11 and Bem1 occurs most likely through Cdc24 in a Bem1-Cdc24Cdc11 complex.

\section{Functional dissection of Bem1 interaction states}

Bem1 is thought to coordinate the activities of its ligands by bringing them into close spatial proximity. To define which combination of binding sites and partners constitute the essential configurations of the Bem1 complex, we first tested mutants and fragments for their ability to complement a deletion of BEM1. BEM1 is not essential in all yeast strains but is required for cell survival in the strain JD47 (Fig 4A) (Dowell et al, 2010). bem1A cells can be rescued by a deletion of the Cdc42 GAP Bem3 but not by the deletion of the Cdc42 GAP Bem2 (Fig 4A) (Laan et al, 2015). Mutating 
A

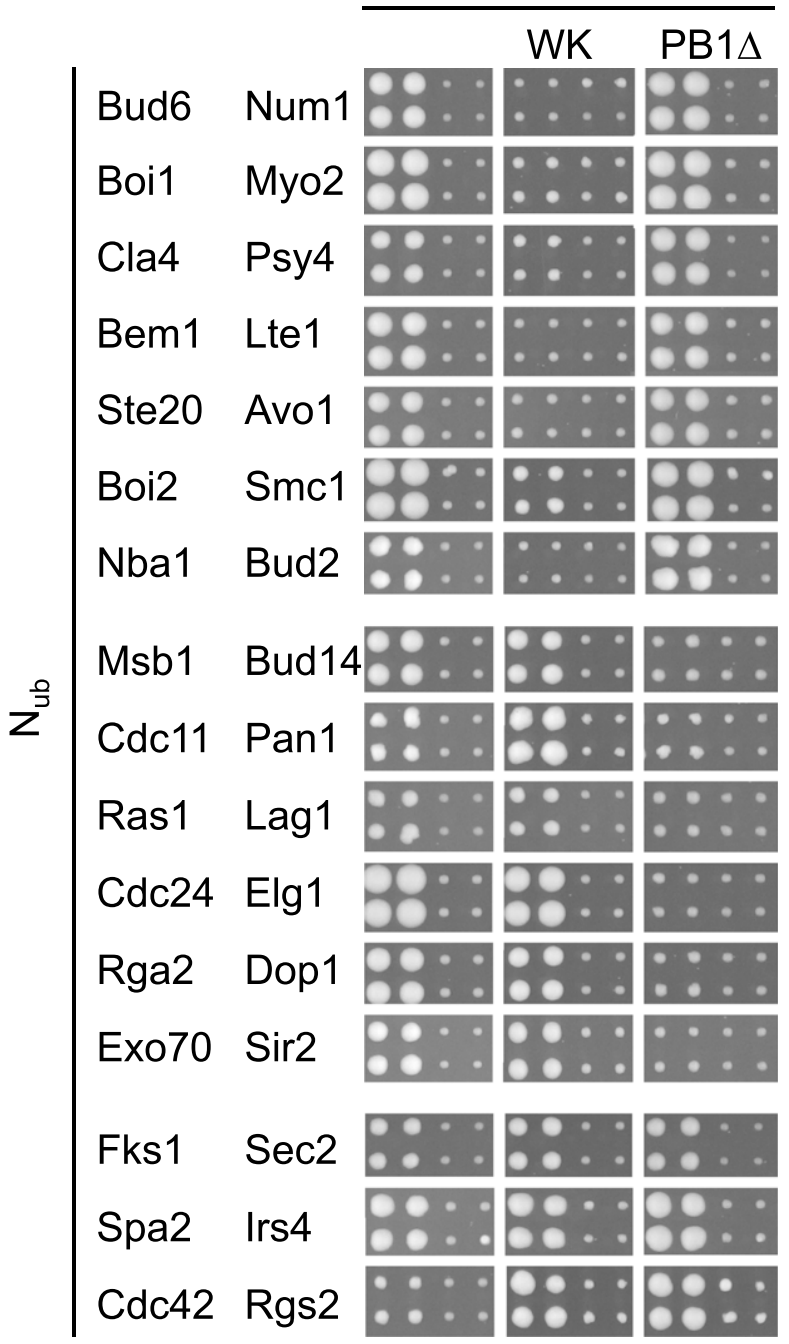

B

\begin{tabular}{|c|c|c|c|}
\hline \multirow[t]{8}{*}{$\mathrm{SH}_{3}$} & $\mathrm{SH}_{3} \mathrm{Cl}$ & $P X$ & PB1 \\
\hline & Bud6 & & Msb1 \\
\hline & Boi1 & & Cdc11 \\
\hline & Cla4 & & Ras1 \\
\hline & Bem1 & & Ras2 \\
\hline & Ste20 & & Rga2 \\
\hline & Boi2 & & Exo70 \\
\hline & Nba1 & & Cdc24 \\
\hline
\end{tabular}

Figure 1. Interaction partners of Bem1.

(A) Yeast cells carrying Bem1CRU or either of its two mutants Bem1 ${ }_{\text {WK }}$ - and Bem1 $1_{\mathrm{PB} 1 \Delta} \mathrm{CRU}$ were independently mated four times with $\mathrm{N}_{\mathrm{ub}}$ fusion expressing strains. Interaction is indicated by growth of the four matings on SD medium containing 5-fluoro-orotic acid. Shown are the cut outs of the quadruplets expressing the $\mathrm{N}_{\mathrm{ub}}$ fusion of the interacting protein on the left, next to a fusion

Bem3's GAP domain or impairing its interaction with lipids was sufficient to restore viability to bem1 $1 \Delta$ cells (Fig S1A). We conclude that a high concentration of cortical $C d c 42_{\text {GTP }}$ can compensate for the loss of Bem1.

The CRIB domain of Gic2 (Gic2 $2_{\mathrm{PBD}}$ ) interacts with Cdc42 $2_{\mathrm{GTP}}$ and has been tagged with red fluorescent protein to monitor active Cdc42 in living yeast cells (Brown et al, 1997; Orlando et al, 2008; Atkins et al, 2013; Okada et al, 2013). The overexpression of Gic2 ${ }_{\mathrm{PBD}}$ is toxic in certain yeast mutants and can be compensated by increasing the amount of Cdc42 (Brown et al, 1997). We introduced GiC2 ${ }_{P B D}$ under control of the methionine-sensitive $\mathrm{P}_{\text {MET17 }}$ - promoter in bem $1 \Delta$ bem $3 \Delta$ cells. Omitting methionine in the media increased the expression of Gic2 $2_{\mathrm{PBD}}$ and eliminated the positive effect of the BEM3 deletion on the survival of bem1 $1 \Delta$ cells (Figs 4A and S4A). The results imply that Gic $2_{\mathrm{PBD}}$ might reduce the free pool of $\mathrm{Cdc} 42_{\mathrm{GTP}}$ at the cell cortex. It follows that Bem1 is needed to stimulate the synthesis and/or to improve the effective use of this pool.

A fragment of Bem1 (Bem1 $1_{145-551}$ ) that covers $\mathrm{SH}_{\mathrm{b}} \mathrm{Cl}$, the PX-, and the PB1 domain and thus keeps the majority of all detected interactions, complemented bem $1 \Delta$ cells (Figs 4B and S2). This region could be further divided into two independently complementing fragments: the $\mathrm{SH}_{3} \mathrm{Cl}$ domain $\left(\mathrm{Bem}_{145-268}\right.$ ) with its binding sites for Cdc42 and for its PxxP ligands Ste20, Cla4, Boi1/2, and the C-terminal fragment containing the PX- and the PB1 domain (Bem1 $268-551$ ) with its binding sites for $\mathrm{Cdc} 24$, lipids, and the other PB1-domain ligands (Figs 1A, 4B and C, and S2). Expressing both fragments together complemented bem1 $\Delta$ cells much better than each fragment alone (Fig 4C).

The autonomy of the central $\mathrm{SH}_{b} \mathrm{Cl}$-domain was unexpected. Single mutations that interrupt the binding of $\mathrm{SH}_{b} \mathrm{Cl}$ either to the PxxP ligands $\left(\mathrm{SH}_{3}{ }_{\mathrm{bwk}} \mathrm{Cl}\right)$ or to $\mathrm{Cdc} 42_{\mathrm{GTP}}\left(\mathrm{SH}_{\mathrm{b}} \mathrm{Cl}_{\mathrm{ND}}\right)$ interfered with the fragment's ability to rescue bem1A cells (Figs 4E and S2) (Yamaguchi et al, 2007; Gorelik \& Davidson, 2012).

The existence of two independently complementing regions explains why none of the single mutations in the $\mathrm{SH}_{b} \mathrm{Cl}$ domain or the deletion of the PB1 domain eliminated the functionality of the otherwise full-length Bem1 (Fig 4B and E). By expressing increasing amounts of Gic $2_{P B D}$, we tested the functionality of the bem1 ${ }_{W K^{-}}$, bem1 $1_{K A^{-}}$, bem1 $1_{N D^{-}}$, or bem1 $1_{W K}$ alleles under conditions of limiting Cdc42 (Fig 4D). All interaction-interfering mutations drastically decreased the tolerance of the cells toward Gic2 ${ }_{\mathrm{PBD}}$ overexpression. The allele bem1 $1_{W K}$ ND bearing both mutations in the $\mathrm{SH} 3_{b} \mathrm{Cl}$ domain conferred a higher sensitivity than the singly mutated bem1 ${ }_{W K^{-}}$or bem1 $1_{N D}$ allele. Overexpressing Bem3 and thus reducing $\mathrm{Cdc42}$ GTP at the cortex by different means had a similar impact (Fig S1B).

We introduced the WK and ND mutations in the different BEM1 copies of a diploid cell to test trans-complementation of the coexpressed Bem1 $1_{W K}$ and Bem1 $1_{N D}$. The undiminished sensitivity of these cells toward Gic2 $2_{\mathrm{PBD}}$ overexpression showed that complementation does not occur in trans and that both binding sites operate within the same Bem1 molecule (Fig 4D).

that does not interact. (B) The domains of Bem1 and the positions of the residue exchanges of the bem1-alleles used in this work. The domain-specific interaction partners of $(\mathrm{A})$ are listed below the respective domains. 
A

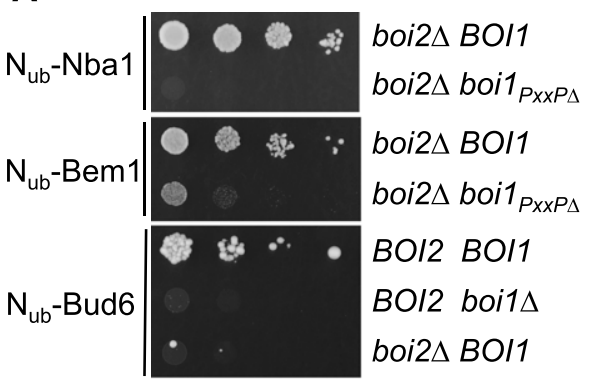

D

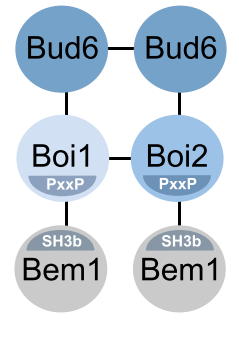

B

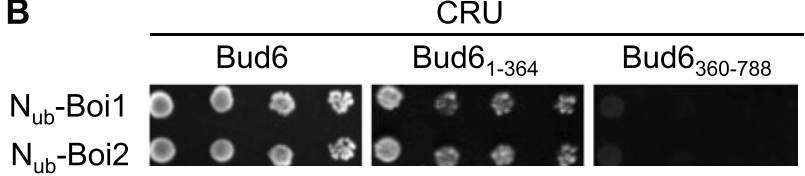

C

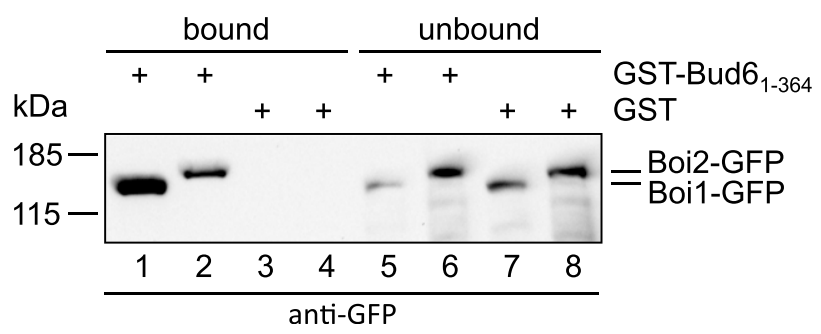

Figure 2. Characterization of the Bem1-Bud6 interaction state.

(A) Yeast cells carrying the indicated mutations were co-expressing CRU fusions to Bem1 together with the indicated $\mathrm{N}_{\mathrm{ub}}$ fusions. Cells were grown to an $\mathrm{OD}_{600}$ of 1 and spotted in 10-fold serial dilutions onto medium containing 5-fluoro-orotic acid. Interactions are indicated by the growth of the yeast cells. (B) As in (A) but with yeast cells co-expressing CRU fusions to Bud6 $6_{1-364}$ or Bud6 $6_{360-788}$, together with $N_{u b}$ fusions to Boi1 and Boi2. (C) Extracts of yeast cells expressing either Boi1-GFP (lanes 1, 3, 5, and 7) or Boi2-GFP (lanes 2, 4, 6, and 8) were incubated with GST- (lanes 3, 4, 7, and 8) or GST-Bud6 ${ }_{1-364}$-immobilized (lanes 1, 2, 5, and 6) sepharose beads. Bound (lanes 1-4) and unbound (lanes 5-8) fractions were analyzed by anti-GFP antibodies after SDS-PAGE and transfer onto nitrocellulose. (D) Model of a potential regulator of actin nucleation. Bud6 is known to homodimerize, whereas Boi1 and Boi2 either homo- or heterodimerize. Bud6 binds and stimulates the yeast formin Bni1 (not shown).

\section{Functional annotation of the $\mathrm{SH}_{\mathrm{b}}$ interactions}

Our findings imply that delivering $\mathrm{CdC}_{\mathrm{C}} 2_{\mathrm{GTP}}$ to one or more of its $\mathrm{SH}_{3}$ ligands constitutes the essential activity of Bem1. Which is the essential binding partner of $\mathrm{SH}_{\mathrm{b}}$ ? The closely spaced $\mathrm{SH} 3_{\mathrm{b}}$ and $\mathrm{Cl}$ domains of Bem1 mirror the $\mathrm{CdC} 42_{\mathrm{GTP}}$ binding of the three of its four ligands Cla4, Ste20, and Boi1. The binding of Cdc42 to Boi2 was not yet investigated. None of the four $\mathrm{SH}_{\mathrm{b}}$ ligands are essential. Cells, however, do not tolerate the loss of both PAKs, or of both Boiproteins (Cvrckova et al, 1995; Bender et al, 1996). To identify the interactions whose loss could phenocopy the WK mutation in $\mathrm{SH}_{\mathrm{b}}$, we introduced mutations in CLA4 (cla4 $4_{F 15 A A A / P P F 451 L}=$ cla4 $\left.4_{P A F L}\right)$,

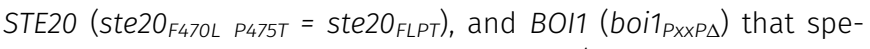
cifically reduce their affinities to $\mathrm{SH}_{\mathrm{b}}$ (Bender et al, 1996; Kozubowski et al, 2008; Gorelik \& Davidson, 2012) (Fig S3). The mutations in STE20 and CLA4 did not impair their interaction with Nbp2, a further ligand of their PxxP motifs (Fig S3) (Winters \& Pryciak, 2005; Hruby et al, 2011; Gorelik \& Davidson, 2012). Which

of the $\mathrm{SH}_{\mathrm{b}}$ interactions become essential under conditions of Gic2 $2_{P B D}$ overexpression? Gic2 $2_{P B D}$ overexpression killed cells lacking CLA4 and the $\mathrm{SH}_{\mathrm{b}}$-binding motif of Ste20, or cells lacking STE20 and the $\mathrm{SH}_{3}$-binding motifs of Cla4, or cells co-expressing Cla4PPAFL with ste20 FLPT (Figs 5A and S4A). Cells lacking BOI2 and the Bem1binding site in Boi1 were not affected by Gic2 ${ }_{\mathrm{PBD}}$ overexpression (Fig $5 \mathrm{~A})$. The pleckstrin homology $(\mathrm{PH})$ domain of Boi1 $\left(\mathrm{PH}_{\text {Boi1 }}\right)$ binds lipid and Cdc42 ${ }_{\mathrm{GTP}}$ (Bender et al, 1996; Kustermann et al, 2017). Overexpression of $\mathrm{PH}_{\mathrm{Boi1}}$ killed cells lacking the physical connection of Bem1 to Ste20 and Cla4 but does not affect cells lacking the connection of Bem1 to Boi1/2 (Fig S1D). A simultaneous overexpression of $\mathrm{Cdc} 42$ suppressed the toxic effect of $\mathrm{PH}_{\text {Boi1 }}$ on ste20 $\Delta$ cla4PPAAFL cells (Fig S1E). We conclude that the PAKs are the essential ligands of the $\mathrm{SH}_{\mathrm{b}}$ domain of Bem 1 under conditions of limiting concentrations of active Cdc42.

Cells without Cla4 or its kinase activity do not correctly assemble septins and display elongated buds (Holly \& Blumer, 1999; Weiss et al, 2000). These phenotypes were recapitulated in bem1 $1_{W K^{-}}$or in bem1 $1_{N D}$ cells, or in cla $4_{\text {PPAAFL }}$ cells upon overexpression of Gic2 $2_{\text {PBD }}$ (Fig 5B-D). In contrast, Gic2 $2_{P B D}$ overexpression did not affect cellular morphology or

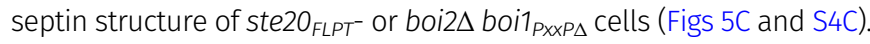
The experiments prove that the Cla4-Bem1-Cdc42 $\mathrm{GTP}$ complex is important during incipient bud site- and septin-assembly.

A deletion of STE2O rescues a strain that is arrested at cytokinesis by the loss of the cytokinesis factors Hof1 and Cyk3 (Atkins et al, 2013; Onishi et al, 2013). It is speculated that Cdc42 inhibits secondary septum formation through activation of Ste20. The loss of Ste20 might prematurely activate secondary septum formation, thus compensating the lack of primary septum. Fig 5E shows that ste $20_{F L P T}$ also rescues hof1 $1 \Delta$ cyk3 $\Delta$ cells. Accordingly, the Ste20Bem1 complex is functionally relevant during cell separation. The same interaction is important for the fusion of cells during mating (Fig S4B) (Winters \& Pryciak, 2005). Again, overexpression of Gic2 2 PBD potentiated the effect of the ste20 FLPT allele (Fig S4B).

The Boi proteins stimulate the fusion of secretory vesicles with the plasma membrane (Kustermann et al, 2017; Masgrau et al, 2017). The small difference in the rate of bud length extension between boir $\Delta$ and boi2 $\Delta$ boi1 $_{\text {PXP } \Delta}$ cells suggests that the interactions between Boi1/2 and Bem1 only modestly affect this activity (Fig S4D).

\section{Boi1/2 anchor Bem1 at the bud tip}

$\mathrm{SH}_{b} \mathrm{Cl}-\mathrm{GFP}$ is the minimal fragment that fully recapitulates the cellular distribution of Bem1-GFP (Fig 6A). The cortical targeting of $\mathrm{SH}_{3} \mathrm{Cl}$ required the ligands of $\mathrm{SH}_{b}$ as $\mathrm{SH}_{b}{ }_{b K} \mathrm{Cl}-\mathrm{GFP}$ stayed $\mathrm{cy}-$ tosolic throughout the cell cycle (Fig $6 \mathrm{~A}$ ). $\mathrm{SH}_{\mathrm{b}} \mathrm{Cl}_{\mathrm{ND}}$-GFP was still concentrated at bud neck and tip. Under the assumption that the N253D exchange completely abrogates Cdc42 ${ }_{\text {GTP }}$ binding, we conclude that $\mathrm{Cdc} 42$ does not contribute to the cortical localization of $\mathrm{SH}_{3}{ }_{b} \mathrm{Cl}$. To find out which of the four $\mathrm{SH}_{b}$ ligands influences the distribution of $\mathrm{SH}_{b} \mathrm{Cl}-\mathrm{GFP}$, we expressed $\mathrm{SH}_{b} \mathrm{Cl}$-GFP in cells each lacking a specific $\mathrm{SH}_{\mathrm{b}}$-binding site. The analysis identified Boi1/2 as the receptor for $\mathrm{SH}_{\mathrm{b}} \mathrm{Cl}$ at the cortex and bud neck (Fig 6B).

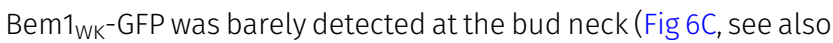
Fig 7), whereas its fluorescence signal at the tip of small and large buds was only modestly reduced (Fig 6C). To obtain a more quantitative measure of tip adherence, we compared the FRAPs 


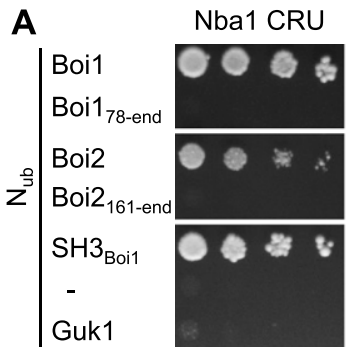

C

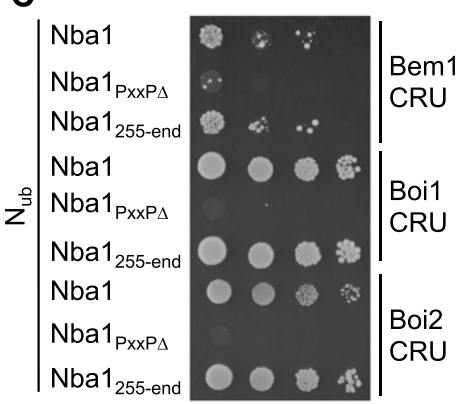

E

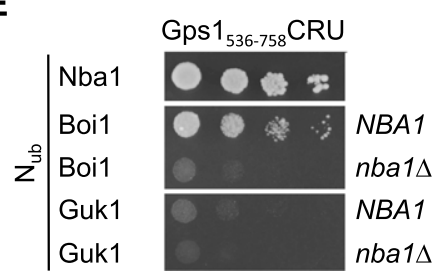

B

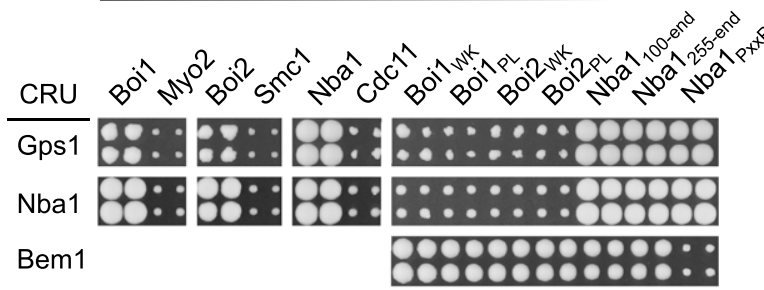

D

$\mathbf{F}$
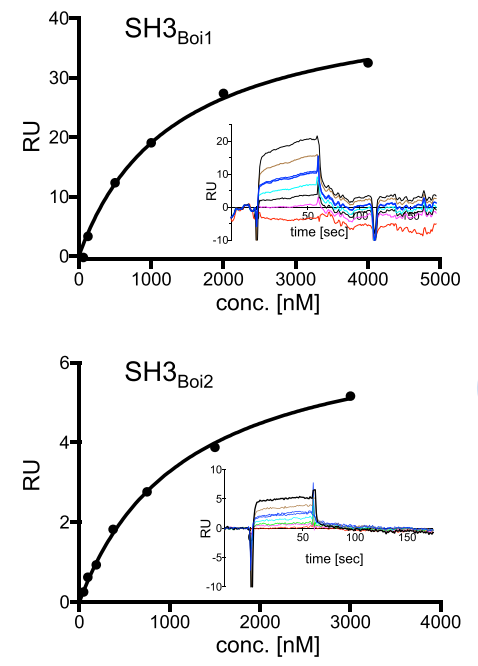

Figure 3. Characterization of the Bem1-Nba1 interaction state.

(A) Split-Ub assay as in Fig 2A, but with cells coexpressing CRU fusions to Nba1 together with the indicated $\mathrm{N}_{\mathrm{ub}}$ fusions. $\mathrm{N}_{\mathrm{ub}}$-Guk1: negative control. (B) a-yeast cells expressing the indicated CRU fusions were mated with $\alpha$-yeast cells expressing the indicated $\mathrm{N}_{\mathrm{ub}}$ fusions and spotted on 5-fluoro-orotic acid medium as in Fig 1A. (C) As in (A) but with yeast cells coexpressing CRU fusions to Bem1, Boi1, or Boi2 togethe with $\mathrm{N}_{\mathrm{ub}}$ fusions to Nba1 or its mutants. (D) Surface plasmon resonance analysis of the interaction between 6 XHIS-Nba1 $202-289$-SNAP and the chip-coated $\mathrm{SH} 3$ domains of Boi1 or Boi2. Shown are

representative plots of the surface plasmon resonance signals as response units against the concentrations of 6XHIS-Nba1 $202-289$-SNAP. Corresponding sensograms are shown as insets. (E) As in (A) but with yeast cells containing or lacking NBA1 and co-expressing Gps1 $1_{536-758} \mathrm{CRU}$ with the indicated $\mathrm{N}_{\mathrm{ub}}$ fusions. (F) Cartoon of the Nba1-Bem1 interaction state. The postulated indirect interaction between Bem1 and Gps1 was not experimentally observed but inferred from the Nba1-dependent interaction between Boi1/2 and Gps1 (see also Fig 7). between the cortex-localized Bem1-GFP, Bem1 ${ }_{W K}-G F P$, and Bem1 ${ }_{\mathrm{ND}^{-}}$ GFP (Fig 6D). The halftime of recovery was not changed by the N253D mutation in Bem1 $\left(t_{1 / 2}=8.82 \pm 1.12 \mathrm{~s}\right)$, whereas the W192K exchange reduced $t_{1 / 2}$ to $4.48 \pm 0.46 \mathrm{~s}$ (Fig $6 \mathrm{D}$ ). A similar reduction in $t_{1 / 2}$ was observed when the FRAPs of Bem1-GFP were compared between boi $\Delta$ cells $\left(t_{1 / 2}=7.35 \pm 0.49 \mathrm{~s}\right)$ and boi2 $\Delta$ cells lacking the Bem1binding sites in Boi1 ( $t_{1 / 2}=5.42 \pm 0.49 \mathrm{~s}$ ) (Fig 6D). The FRAP of the cortex-localized Bem1 was not changed in cells where the interactions between Bem 1 and the PAKs were eliminated (ste20 $\Delta$ cla4 ${ }_{\text {PPAAFL }}$ ) (Fig 6D).

Boi1 and Boi2 associate with the bud cortex mainly through their Cdc42 GTP- and lipid-binding PH domains (Hallett et al, 2002). Bem1 also contains multiple phospholipid-binding sites (Hallett et al, 2002; Meca et al, 2019). Boi1/2 and Bem1 might, thus, cooperatively recruit each other to the bud cortex. In accordance, Boi1 $1_{\text {PxP }}$-GFP carrying a mutated Bem1-binding site was significantly more mobile

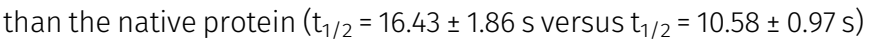
(Fig 6E). Boi1-GFP was also slightly less focused at the bud cortex of bem1 $1_{w K}$ cells. bem1 $1_{w K}$ did not detectably influence the cortical localization of Ste20-GFP or Cla4-GFP (Fig 6F and G) (Winters \& Pryciak, 2005).

\section{Nba1 and Fir1 anchor Boi1/2-Bem1-Cdc24 at the bud neck}

Bem1 leaves the cortex during mitosis and arrives at the bud neck shortly before the acto-myosin ring contraction is completed (Fig S4E). Boi1/2 link Bem1 and Cdc24 to the neck (Figs 6B and 7C), as mutations in their SH3 domains removed both proteins from the neck (Fig 7C) (Hallett et al, 2002). Nba1 is a potential docking site for Boi1/2 as it binds to both SH3 domains and arrives at the neck at roughly the same time as Bem1 (Fig 3) (Meitinger et al, 2014). Accordingly, a deletion of NBA1 or of its Boi1/2-binding site (Nba1 PxxPA $_{\text {) }}$ removed Boi2-GFP completely, and 55\% of Boi1-GFP (Fig 7B). The Nba1-mediated interaction between Gps1 and Boi1/2 suggests that Gps1 anchors the Nba1-Boi1/2-Bem1-Cdc24 complex at the neck (Fig $3 F$ and E). Accordingly, gps1 $1 \Delta$ cells lacked Nba1-GFP at the bud neck and reduced neck localizations of Boi1-GFP and Boi2-GFP to a similar extent as nba1A cells (Fig 7A and B) (Meitinger et al, 2014). The localization of the isolated $\mathrm{SH}_{3}{ }_{\text {Boi1 }}$ or $\mathrm{SH}_{3}{ }_{\text {Boi2 }}$ mirrored the $\mathrm{SH} 3$ dependencies of the full-length proteins (Fig 7B). However, $t_{1 / 2}$ of

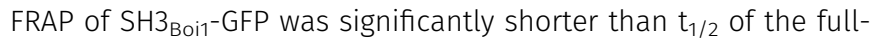
length Boi1-GFP ( $t_{1 / 2}=0.7 \mathrm{~s}$ versus $t_{1 / 2}=12 \mathrm{~s}$; Fig 7D), indicating that regions beyond $\mathrm{SH}_{\text {Boi1 }}$ contribute to neck localization. Bem1 was reported to directly bind to Nba1 (Meitinger et al, 2014). However, Boi $_{\text {PXXP }}$-GFP lacking the binding site to Bem1 still displayed $a t_{1 / 2}$ of $10 \mathrm{~s}$ at the bud neck that is very similar to the $t_{1 / 2}$ of FRAP of the wildtype protein (Fig 7D). We conclude that Boi1 recruitment to the neck is distinct from its synergistic recruitment to the tip.

Bem1-GFP and Cdc24-GFP completely disappeared from the bud neck of cells expressing $\mathrm{SH} 3$ mutations in both Boi proteins (boi1 ${ }_{W K}$ boi2 $w_{\text {K }}$, Fig 7C). In contrast, nba1 ${ }_{P \times X P \Delta^{-}}$or gps1 1 cells still kept $\sim 69 \%$ of Cdc24-GFP and 58\% of Bem1-GFP at the neck (Fig 7C). Whereas Boi2 was solely attached by Nba1-Gps1, $45 \%$ of Boi1 were still visible in nba1 $_{P \times X \Delta^{-}}$, or gps1 $1 \Delta$ cells. 
A

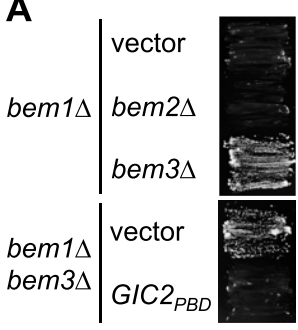

C

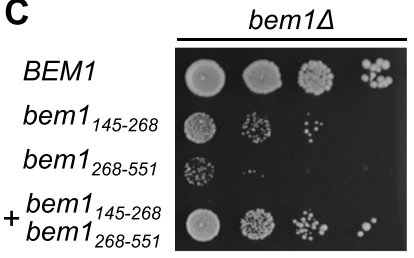

B

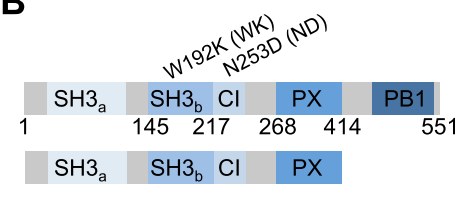

\begin{tabular}{|c|c|c|c|}
\hline $\mathrm{SH}_{3}$ & $\mathrm{Cl}$ & $\mathrm{PX}$ & PB1 \\
\hline $\mathrm{SH}_{3}$ & $\mathrm{Cl}$ & $P X$ & \\
\hline
\end{tabular}

$\mathrm{SH}_{\mathrm{b}} \mathrm{Cl}$

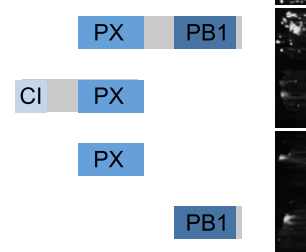

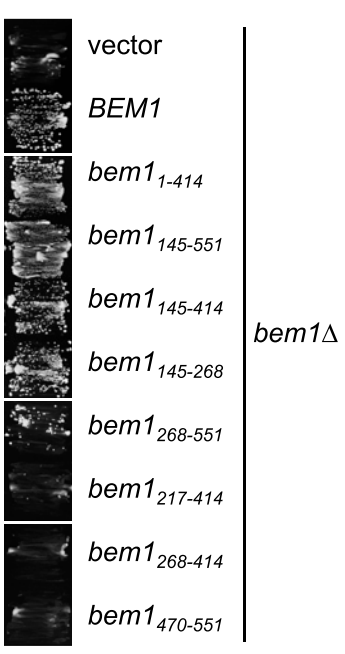

E
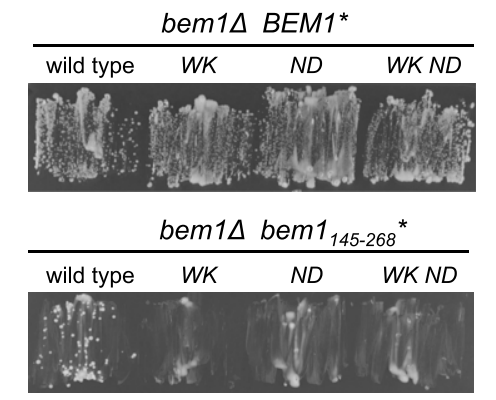

Figure 4. Bem1 contains two functionally independent regions.

(A) bem1 $1 \Delta$ cells expressing a vector-encoded BEM1 and carrying an additional gene deletion as well as an empty vector, or a vector expressing Gic2 ${ }_{\mathrm{PBD}}$, were incubated on media selecting against the presence of the plasmid-encoded BEM1. (B) bem1 $1 \Delta$ cells carrying a vector-encoded $B E M 1$ and a vector-expressing Bem1 or the indicated fragments of BEM1 (left panel) were incubated on medium selecting against the vectorencoded BEM1 (right panel). (C) bem1 $1 \triangle$ cells expressing $B E M 1$ or the indicated fragments of $B E M 1$ were spotted in 10 -fold serial dilutions onto the SD medium selecting for the presence of the plasmids and incubated at $37^{\circ} \mathrm{C}$. (D) Haploid cells (upper panel), or diploid cells (lower panel) carrying the indicated alleles of BEM1 were incubated in 10-fold serial dilutions on media inducing the expression of Gic $2_{\mathrm{PBD}}$ to moderate (left panels) or high (right panels) levels. (E) bem1 $1 \Delta$ cells carrying a vector-encoded BEM1 and additionally expressing the full-length $B E M 1$ with the indicated residue exchanges (upper panel), or fragments of BEM1 with the indicated residue exchanges (lower panel), were incubated on medium selecting against the vector-encoded BEM1.

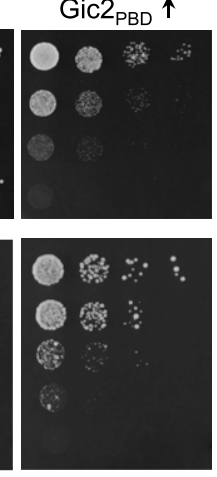

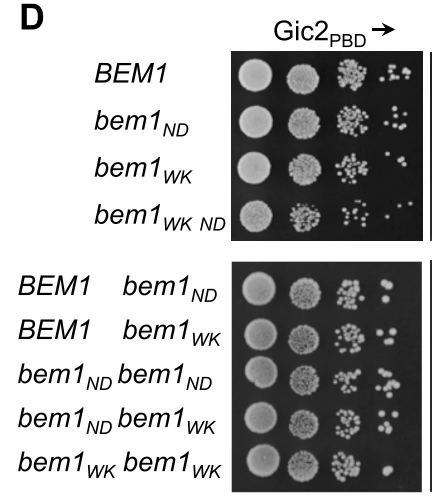

Which protein is the alternative anchor for Boi1 at the site of cell separation? The neck localization as well as its interaction with Boi1/2 makes Fir1 a candidate for this role (Brace et al, 2019; Tonikian et al, 2009). Split-Ub analysis confirmed the complex between Boi1/2 and Fir1 and could further demonstrate that the interactions depend on the functional $\mathrm{SH}_{\text {Boir }}$ or $\mathrm{SH}_{\text {Boiz }}$ and the

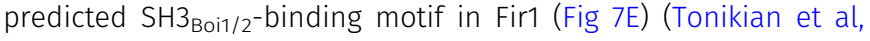
2009). We next introduced the GFP fusions of Boi1, $\mathrm{SH}_{\text {Boi1 }}$, and the Cdc24-Bem1 complex in strains lacking FIR1 (fir1 $\Delta$ ), lacking the Boi1binding motif in FIR1 ( fir $\left._{P \times X P \Delta}\right)$, or in cells lacking the motifs in FIR1 and NBA1 ( b $1_{P_{X X P \Delta}}$ fir $\left._{P \times X P \Delta}\right)$ (Fig 7B and C). Quantifying the intensities of the GFP signals proved that Fir1 recruits the Boi1Bem1-Cdc24 complex independently of Nba1 to the bud neck. Boi1 was equally distributed between Nba1 and Fir1 (Fig 7B). In contrast, proportionally more of $\mathrm{Cdc} 24$ was anchored through Fir1 than through Nba1, whereas the amount of neck-anchored Bem1 did not change upon removal of the Boi1-binding site in Fir1 (Fig 7C and F for a model).

\section{Temporal dissection of the Bem1 interaction network}

To find out whether Bem1 might bring together different interaction partners at different phases of the cell cycle, we characterized the time dependency of a subset of its interactions through Split-Ub analysis using two spectrally different fluorescent proteins as sensors for interaction (SPLIFF) (Moreno et al, 2013). Here, the $\mathrm{C}_{\mathrm{ub}}$ is sandwiched between the auto-fluorescent mCherry and GFP (CCG) (Moreno et al, 2013). Upon interaction-induced reassociation with an $N_{u b}$ fusion, the GFP is cleaved off and rapidly degraded. The subsequent local increase in the ratio of red to green fluorescence indicates where and when the direct or indirect interaction between both proteins took place (Moreno et al, 2013).

A Bem1-mCherry-Cub-RGFP fusion protein (Bem1CCG) was expressed from its genomic locus under the control of the conditional MET17 promoter in MATa cells. All $\mathrm{N}_{\mathrm{ub}}$ fusions were expressed in $\alpha$-cells from their native promoters, except $\mathrm{N}_{\mathrm{ub}}$-Cdc42 and $\mathrm{N}_{\mathrm{ub}}$-Exo70 that were under control of the non-induced $\mathrm{P}_{\text {CUP1 }}$ promoter. $\mathrm{N}_{\mathrm{ub}}$-Rsr1 was included in the analysis as it generated under its native expression levels a strong interaction signal with Bem1CRU (Fig S4F). Mating and fusion of the a- and $\alpha$ cells allowed Bem1CCG and the respective $N_{u b}$ fusion to interact. Green and red fluorescence were then measured during one cell cycle at the site of cell fusion (PCDI), at the cell front during bud site assembly and bud growth (PCDII), and finally at the bud neck from completion of acto-myosin ring contraction until cell abscission (PCDIII) (Fig S4G). The ratios of the fluorescence intensities (IFs) from individual single-cell experiments were fitted into a single curve and plotted as percentage of $\mathrm{N}_{\mathrm{ub}}$-induced conversion of Bem1CCG to Bem1CC against time after cell fusion (Fig 8 and Table S1). A regressionbased significant positive slope over two time intervals was taken 
A
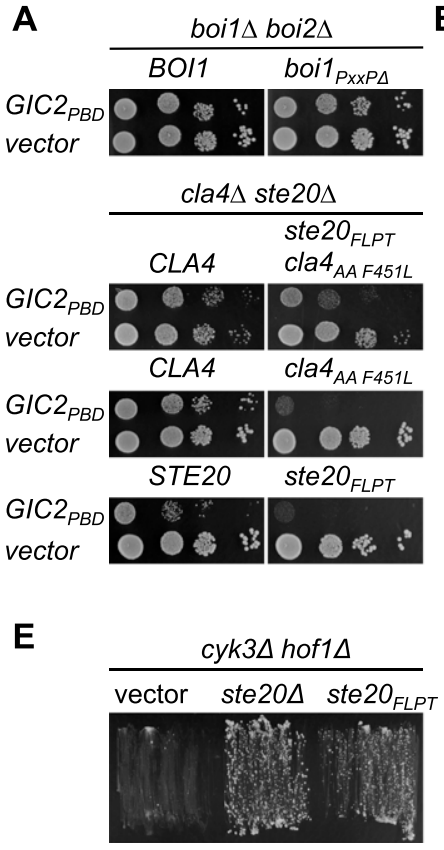
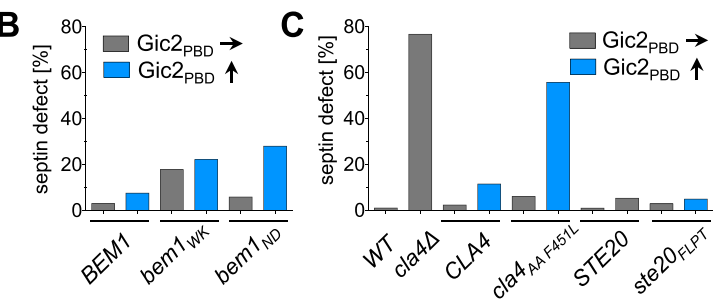

D

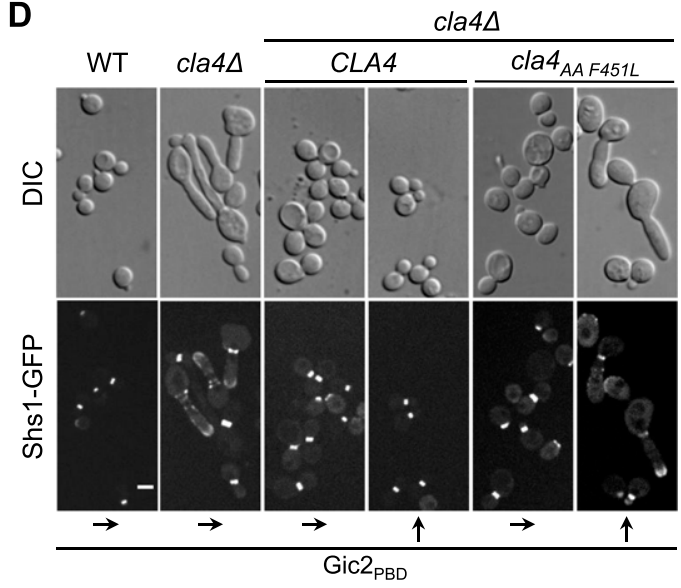

Figure 5. The connection between Bem1 and the PAKs is essential upon overexpression of Gic2 2 PBD.

(A) Yeast cells carrying the indicated alleles and either Gic $2_{\mathrm{PBD}}$ or an empty vector were spotted in 10-fold serial dilutions on medium inducing high levels of Gic2 2 PBD. (B) Cells expressing Shs1-GFP, the indicated alleles of $B E M 1$, and Gic2 ${ }_{\mathrm{PBD}}$ were incubated under conditions of low (70 $\mu \mathrm{M}$ Met, gray bars) or high expression levels ( 0 Met, blue bars) of Gic2 2 PBD. Cells $(500<n<600)$ were classified according to their native-like or abnormal distribution of the Shs1-GFP. (C) As in (B) but with cells $(500<n<600)$ carrying the indicated alleles of STE20 or CLA4. (D) Microscopy of the cells of (C). Upper panel: DIC channel. Lower panel: GFP channel. Scale bar indicates $3 \mu \mathrm{M}$. (E) cyk3 $\Delta$ hof $1 \Delta$ cells expressing HOF1 from an extra-chromosomal vector and carrying the indicated alleles of STE2O or an empty vector were incubated on media selecting against the HOF1containing vector. as evidence for interaction (Figs 8B and S5 and Table S2). No significant increase or a decrease in the relative amount of conversion was considered as absence of interaction. It is important to remind that the absence of an interaction signal indicates "no interaction" only within the detection limit of SPLIFF. The interaction partners of Bem1 fall into the following categories: Ste20, Cdc24, Rsr1, Boi1, Boi2, and Cdc42 interacted with Bem1 during all three phases (Figs $8 \mathrm{~A}$ and $B$ and S5 and Tables S1 and S2). Cla4 interacted with Bem1 only during PCDI and II. Bud6 interacted with Bem1 only during bud formation and growth (PCDII). Nba1 interacted with Bem1 shortly during PCDI and throughout cytokinesis (PCDIII), whereas Exo70 interacted during PCDII, and in PCDIII, only shortly before cell separation (Figs 8 A and B and S5 and Table S2). The multimerization of Bem1 could be observed during a single time frame in PCDI and throughout PCDII. We can, further, differentiate between Bem1 interactions that last through the entire PCDII (Bem1, Boi1, Exo70, Cdc42, and Cdc24) and those that are detectable in small buds only (Bud6 and Rsr1) (Figs 8A and B and S5 and Table S2). The interaction between Bem1 and Rga2 stalled during bud formation and picked up after 10 min into bud growth to continue as long as Bem1 remained at the cortex (Figs 8 and S5 and Tables S1 and S2). The interaction signals between Bem1 and Boi1, Boi2, Cla4, and Ste20 reached a plateau after 20 min into bud growth. The slight increase of conversion was considered as sign of a continuing yet diminished interaction between Bem1 and Boi1 during the remaining phase of bud growth (Figs $8 \mathrm{~A}$ and $\mathrm{B}$ and $\mathrm{S} 5$ and Table S2). The decrease in the ratio of converted Bem1CCG in the $\mathrm{N}_{\mathrm{ub}}{ }^{-}$ Ste20-, $\mathrm{N}_{\mathrm{ub}}$-Cla4-, and $\mathrm{N}_{\mathrm{ub}}$-Boi2-expressing cells might already indicate a loss of interaction between Bem1 and the $\mathrm{N}_{\mathrm{ub}}$ fusions during the transition from bud growth to mitosis. However, it has to be noted that conversion ratios at or above $80 \%$ are very difficult to interpret and that no increase or a slight decrease do not necessarily have to reflect the absence of interaction. During cytokinesis, Boi1/2, Ste20, Rsr1, Cdc24, Cdc42, Exo70, and Nba1 were detectably associated with Bem1 (Figs 8 and S5 and Tables S1 and S2), whereas $\mathrm{N}_{\mathrm{ub}}$-Cla4, $\mathrm{N}_{\mathrm{ub}}{ }^{-}$ Bud6, $\mathrm{N}_{\mathrm{ub}}$-Rga2, and $\mathrm{N}_{\mathrm{ub}}$-Bem1 did not convert Bem1CCG during abscission (PCDIII, Figs 8A and B and S5 and Tables S1 and S2).

\section{$\mathrm{SH}_{\text {Boi1 }}$ switches between interaction partners during the cell cycle}

The detection of the Bem1-Bem1 interaction requires the oligomerization of the Boi proteins, whereas the proximity between Bem1 and $\mathrm{Nba} 1$ is mediated by the simultaneous interactions of both proteins with Boi1/2 (Figs 2 and 3).

We tested the consistency of our SPLIFF analysis by measuring Boi1CCG against $\mathrm{N}_{\mathrm{ub}}$-Boi1 and $\mathrm{N}_{\mathrm{ub}}$-Nba1. In agreement with the time dependency of Bem1 multimerization and the formation of the Nba1-Bem1 complex, Boi1CCG was converted to Boi1CC by $\mathrm{N}_{\mathrm{ub}}$-Boi1 during bud growth and not during abscission, whereas Boi1CCG was converted by $\mathrm{N}_{\mathrm{ub}}$-Nba1 only during abscission (Figs $8 \mathrm{~B}$ and $9 \mathrm{C}$ and Tables S1 and S2). Boi1CCG / $\mathrm{N}_{\mathrm{ub}}-\mathrm{Nba1}$, thus, lacked the interaction signal observed between Bem1CCG and $\mathrm{N}_{\mathrm{ub}}$-Nba1 during PCDI. The reported Boi1/2-independent interaction between Bem1 and Nba1 might account for this apparent discrepancy (Fig 8) (Meitinger et al, 2014). The high level of Boi1CCG conversion at the beginning of PCDIII might indicate that Boi1/2-Bem1 arrive together with Nba1 as a preformed complex at the bud neck. The time resolution of our assay cannot distinguish this scenario from our preferred interpretation that conversion occurred exclusively at the neck.

Besides binding to $\mathrm{Nba} 1$ and Fir1, $\mathrm{SH}_{\text {Boi1/2 }}$ interact with additional proteins and might expand the influence of the Bem1-Cdc24 complex to further processes (Tonikian et al, 2009; Kustermann 
A

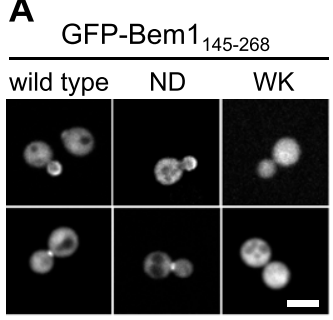

B

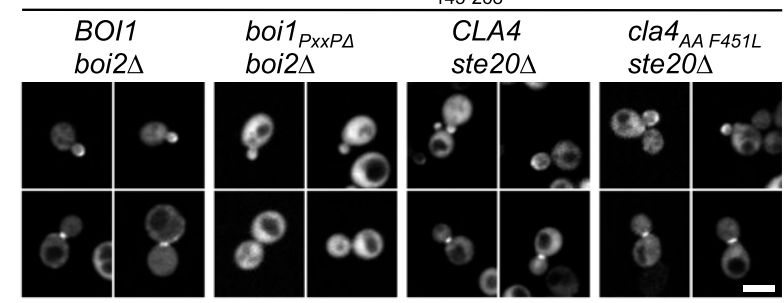

C

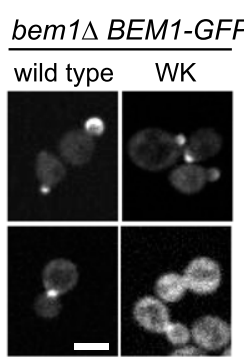

E

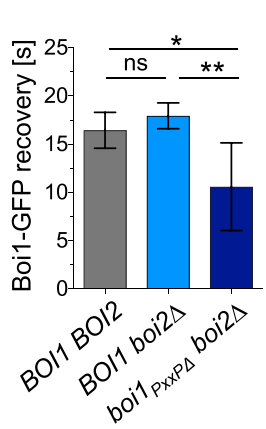

D

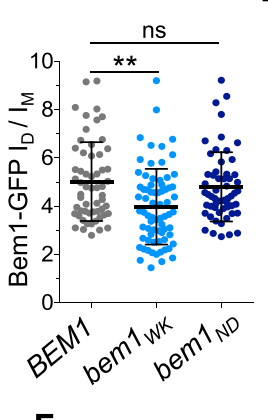

$\mathbf{F}$
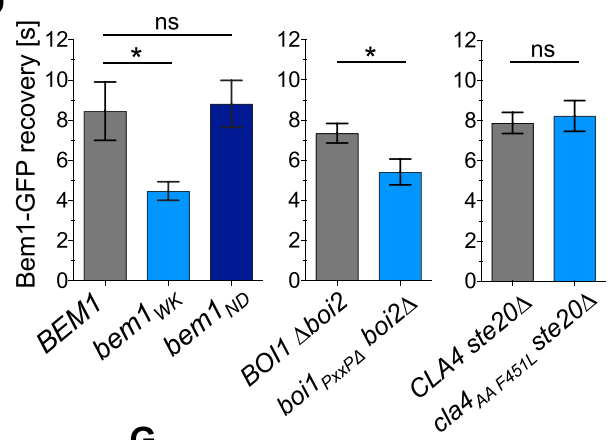

G

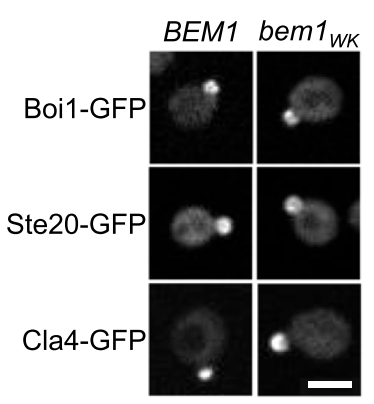

\section{2}

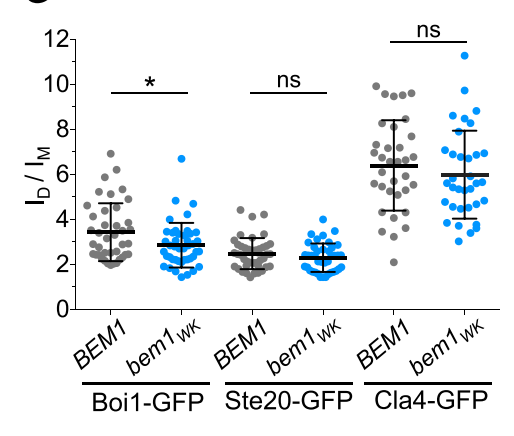

Figure 6. Boi1 and Boi2 localize Bem1-Cdc24 at bud tip and neck.

(A) Wild-type cells expressing GFP-Bem1 $1_{145-268}$ (left panel) or GFP-Bem1 145-268 carrying the ND (middle panel) or WK (right panel) exchange were inspected by fluorescence microscopy. (B) Cells of the indicated genotypes expressing GFP-Bem1 $1_{145-268}$ were inspected by fluorescence microscopy (left panel). Only boiz $\Delta$ boi1 $1_{\text {XXP }}$ cells show a clear misdistribution of GFP-

Bem1 145-268. (C) Left panel: bem1 $1 \Delta$ cells expressing Bem1GFP or Bem1 $1_{\text {wk }}$-GFP were inspected by fluorescence microscopy. Right panel: Quantification of the intensity ratios of Bem1-GFP $(n=58)$, Bem1 ${ }_{w k}-$ GFP $(n=72)$, and Bem1 $1_{N D}-G F P(n=57)$ in bud and mother cells. (D) Halftimes of fluorescence recovery after photo-bleaching the bud of cells expressing Bem1-GFP or its mutants. Left panel: Bem1-GFP $(n=11), B_{1 e m 1}-G F P(n=18)$, or Bem1 $_{N D}-G F P(n=24)$. Middle panel: Bem1-GFP in boi2 $\Delta$ BOl1 cells $(n=20)$ or boi2 $\Delta$ boi1 $_{\triangle P X X P}$ cells $(n=16)$. Right panel: Bem1-GFP in ste20 $\triangle$ CLA4 cells $(n=16)$ or ste20 $\Delta$ cla4 PPAAFL cells $(n=14)$. (E) As in (D) but with BO/1 BOI2 cells $(n=23)$, boi2 $\Delta O 11$ cells $(n=24)$, or boi2 boi1 $1_{P \times P \Delta}$ cells $(n=22)$ expressing GFP fusions to $B O / 1$ or boi1 $1_{P X P \Delta .}$. (F) Bem1 cells (left panel), or Bem1 $1_{W K}$ cells (right panel) expressing GFP fusions to Boi1 (upper row), Ste20 (middle row), or Cla4 (lower row), were inspected by fluorescence microscopy. $(\mathbf{F}, \mathbf{G})$ The ratios of the fluorescence intensities of bud and mother cells from (F) were quantified in BEM1- and bem1 wK $_{\text {c }}$ cells expressing Boi1-GFP $(n=40,43)$, Ste20-GFP $(n=43,40)$, or Cla4-GFP $(n=34,34)$. ns, not significant. ${ }^{*}=P<0.05$, $* *=P<0.01$. Scale bars indicate $3 \mu \mathrm{M}$. et al, 2017). To test whether other $\mathrm{SH}_{\text {Boi }}$ interactions are also cell cycle-specific, we investigated the interaction between Epo1 and Boi1. Epo1 links the cortical endoplasmic reticulum to the polarisome and was shown to bind Boi1/2 (Neller et al, 2015). Mutations that inactivate $\mathrm{SH}_{\text {Boi1 }}$ or a mutation of the predicted Boi1-binding motif in Epo1 abolished the interaction between both proteins (Fig 9A). A pull down of this binding motif with a GST fusion to $\mathrm{SH}_{\text {Boir }}$ proved its direct interaction (Fig 9B). Epo1 and Nba1 thus compete for the same binding site in Boi1. SPLIFF picked up the interaction between $\mathrm{N}_{\mathrm{ub}}$-Boi1 and Epo1CCG for the first time during bud growth (Figs $9 \mathrm{C}$ and S5 and Tables S1 and S2). No interaction could be recorded for Epo1 during PCDIII at the bud neck (Fig 9C). Although sharing the same interaction site, Epo1 and Nba1 interacted with Boi1-Bem1 at different stages of the cell cycle.

\section{Discussion}

Bem1 is a central scaffold protein for the Cdc42 pathway that is essential in some but not all Saccharomyces cerevisiae strains (Dowell et al, 2010). Eliminating the GAP activity of Bem3 and thus increasing the concentration of active $\mathrm{Cdc42}$ at the cortex especially during bud formation rescues the otherwise lethal deletion of BEM1 in the strain JD47, whereas the overexpression of a Cdc42 GTP- and membrane-binding fragment of Gic2 counteracts the positive effect of the BEM3 deletion (Knaus et al, 2007). Whether yeast cells of a certain strain can live without Bem1 thus seems to depend on the remaining concentration of active Cdc42 at the cortex. A central fragment of Bem1 harboring the $\mathrm{SH}_{\mathrm{b}}$ domain with its neighboring $\mathrm{CdC} 42_{\mathrm{GTP}}$ binding element and a C-terminal fragment, containing the PB1 and PX domain, independently rescue a bem1 $1 \Delta$ strain. The C-terminal fragment binds strongly to $\mathrm{Cdc} 24$ but does not connect Cdc24 to Cdc42 effector proteins or to the cortex. We propose, in line with published data, that the C-terminal fragment increases the concentration of Cdc42 $\mathrm{GTP}$ by stimulating the activity of Cdc24 (Shimada et al, 2004; Smith et al, 2013; Rapali et al, 2017). The central $\mathrm{SH}_{\mathrm{b}} \mathrm{Cl}$ fragment interacts with active Cdc42 and four Cdc42 effectors and requires both of its binding sites to rescue bem1 $\Delta$ cells. Our genetic analysis and published data suggest that the functional units $\mathrm{SH}_{3}, \mathrm{Cl}$, and PB1 of Bem1 co-operate and form a chain of binding sites that funnel active $\mathrm{Cdc} 42$ from its source to its targets (Kozubowski et al, 2008).

Ste2 2 and $\mathrm{Cla} 4$ are the essential ligands of $\mathrm{SH}_{\mathrm{b}} \mathrm{Cl}$ under limiting concentrations of $\mathrm{Cdc}_{4} 2_{\mathrm{GTP}}$ (Fig $5 \mathrm{~A}$ ). How can the isolated $\mathrm{SH} 3 \mathrm{bCl}$ 
A

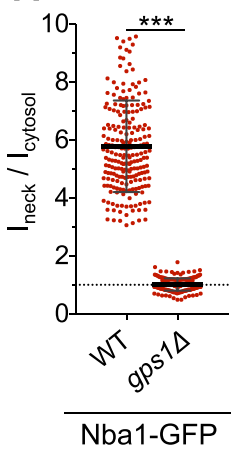

B

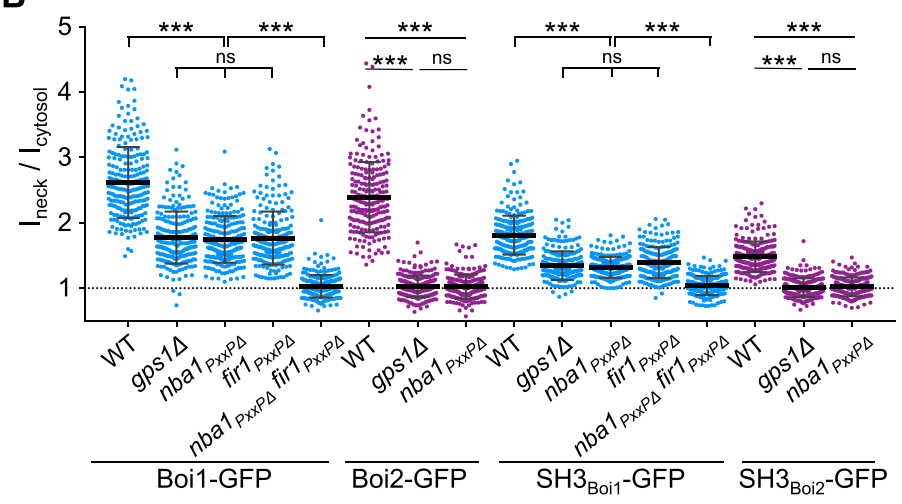

C

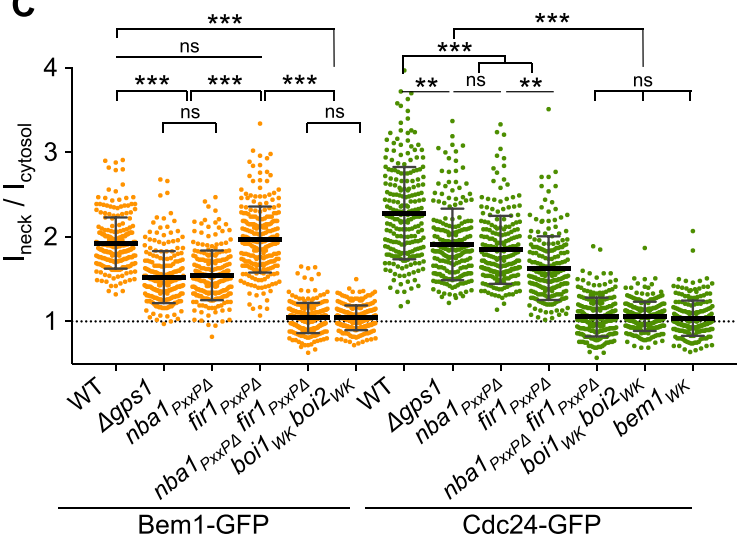

D

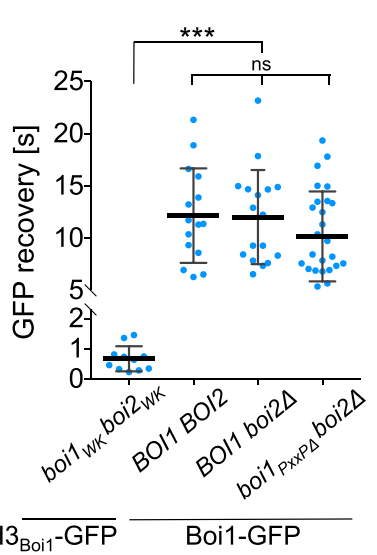

E

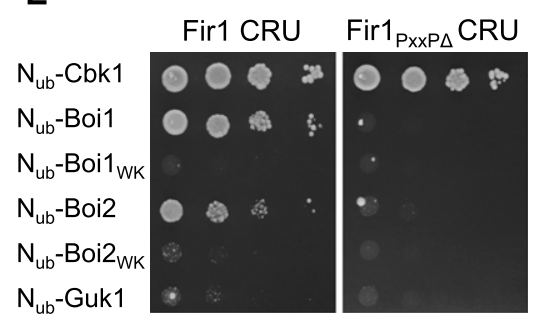

$\mathbf{F}$

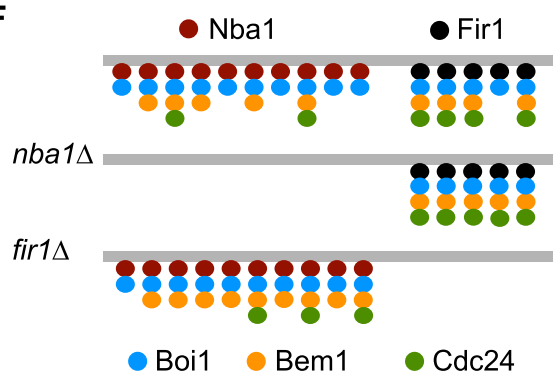

Figure 7. Two receptor systems attach Bem1-Cdc24 to the bud neck.

(A) Ratios of bud neck to cytosolic fluorescence intensities of Nba1-GFP in wild type and gps1 $1 \Delta$ cells. (B) As in (A) but in cells of the indicated genotypes expressing Boi1-GFP, Boi2-GFP, SH3 $3_{\text {Boi1 }}-G F P$, and

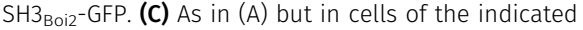
genotypes expressing Bem1-GFP or Cdc24-GFP. (D) Fluorescence recovery after photo bleaching the bud neck of boi1 WK $_{\text {boi }}$ bK cells expressing $\mathrm{SH}_{\text {Boi1 }}$-GFP $(n=11)$, of wild type cells expressing Boi1-GFP $(n=15)$, of boi2 $\Delta$ cells expressing Boi1-GFP $(n=17)$, of boi2 $\Delta$ cells expressing Boi1 $1_{P X P \Delta}-G F P(n=27)$. (E) Split-Ub analysis as in Fig 2A but with cells expressing Fir1CRU or Fir1 $_{\text {PxxP }} \mathrm{CRU}$ together with indicated $\mathrm{N}_{\mathrm{ub}}$ fusions. $\mathrm{N}_{\mathrm{ub}}{ }^{-}$ Cbk1: positive control; $\mathrm{N}_{\mathrm{ub}}$-Guk1: negative control. (F) Anchoring the Bem1-Cdc24 complex at the bud neck in wild type- (upper panel), nba1s- (middle panel), and fir1 $\Delta$ cells (lower panel). Nba1 (red dots) and Fir1 (black dots) recruit Boi1 (blue dots) (for simplicity only Boi1 is shown), which recruits the Bem1-Cdc24 complex (orange and green dots). To explain the impact of the mutations on the distributions of the different proteins, we assume that Nba1 outnumbers Fir1 at the neck, that Nba1 and Fir1 are saturated by Boi1/2, the number of $\mathrm{Nba} 1$ and Bem1 molecules are similar, and that Nba1 reduces the affinity between $\mathrm{Cdc} 24$ and Bem1 (Meitinger et al, 2014) without connection to Cdc24 still stimulate the PAKs? A comparison between the binding characteristics of the non-essential Boi1/2PxxP sites and the essential Ste20/Cla4-PxxP sites suggests a molecular mechanism. Bem1 and all its SH3b ligands are concentrated at the cell tip during bud formation and growth. The cortex localizations of the PAKs but not of Boi1/2 strictly depend on Cdc42 GTP (Peter et al, 1996; Leberer et al, 1997; Wild et al, 2004; Kustermann et al, 2017). The isolated binding motifs of Cla 4 and of Boi1/2 bind with similar affinities to $\mathrm{SH}_{\mathrm{b}}$, whereas the $\mathrm{SH}_{\mathrm{b}}{ }^{-}$ binding motif of Ste20 displays a significantly higher in vitro affinity (Gorelik \& Davidson, 2012). SPLIFF analysis shows that both PAKS and Boi1/2 interact with Bem1 during bud formation and growth. Nevertheless, and in contrast to Boi1/2, both PAKs do not measurably contribute to the cortical localization of $\mathrm{SH} 3_{b} \mathrm{Cl}$ or of fulllength Bem1. We hypothesize that Bem1 interacts stronger with the inactive PAKs than with their cortex-localized $\mathrm{Cdc42} 2_{\mathrm{GTP}}$-bound forms. To explain the stimulatory activity of $\mathrm{SH}_{b} \mathrm{Cl}$, we postulate that $\mathrm{SH}_{3} \mathrm{Cl}$ might open the CRIB domains of the PAKs to actively load them with the $\mathrm{Cl}$-attached $\mathrm{Cdc42}$ GTP (Lamson et al, 2002). The Cdc42 GTP-bound CRIB domain might then release the autoinhibition of the kinases and at the same time, impair the interaction with $\mathrm{SH}_{\mathrm{b}}$. This sequence describes Bem 1 not as a passive scaffold but more similar to the kinase scaffold Ste 5 as a coactivator that regulates through binding the activity of the PAKs and stimulates the synthesis and the transfer of Cdc42 (Bhattacharyya et al, 2006). Support for our model comes from two observations: 1. Bem1 needs the fully functional $\mathrm{SH} 3 \mathrm{bCl}$ to activate Ste20 and Cla4 also during osmostress (Chang et al, 1999; Tanaka et al, 2014). 2. Scd2, the Bem1 homolog from Schizosaccharomyces pombe, binds with its second SH3 domain the Ste20 homologs Shk1 and thereby increases the auto-phosphorylation activity of the kinase (Chang et al, 1999; Tanaka et al, 2014). 


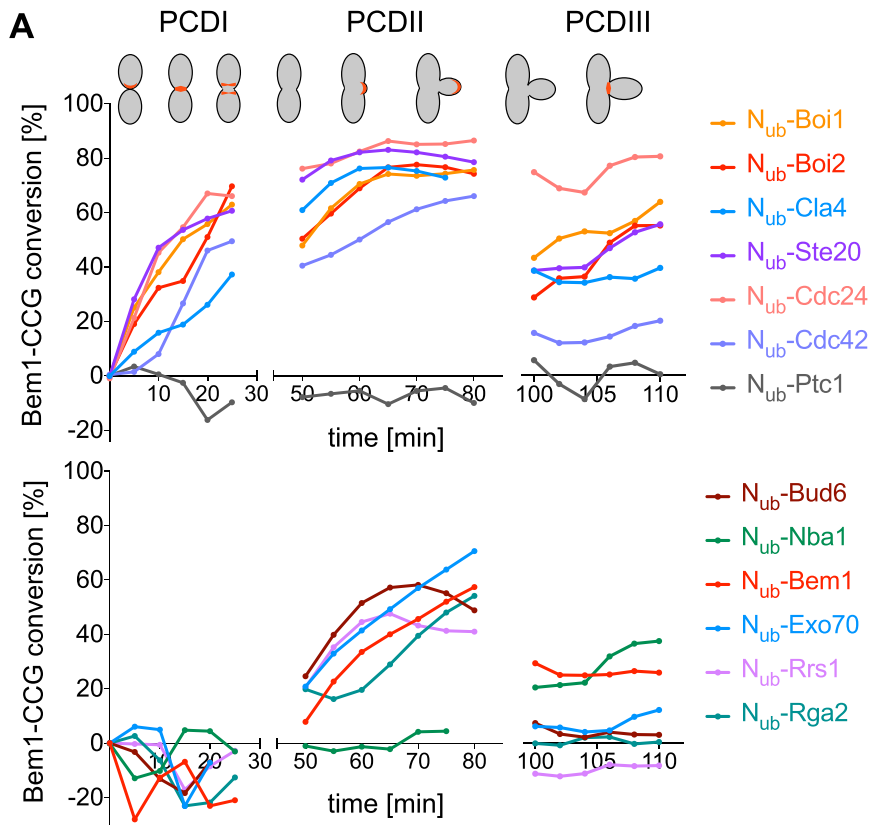

B

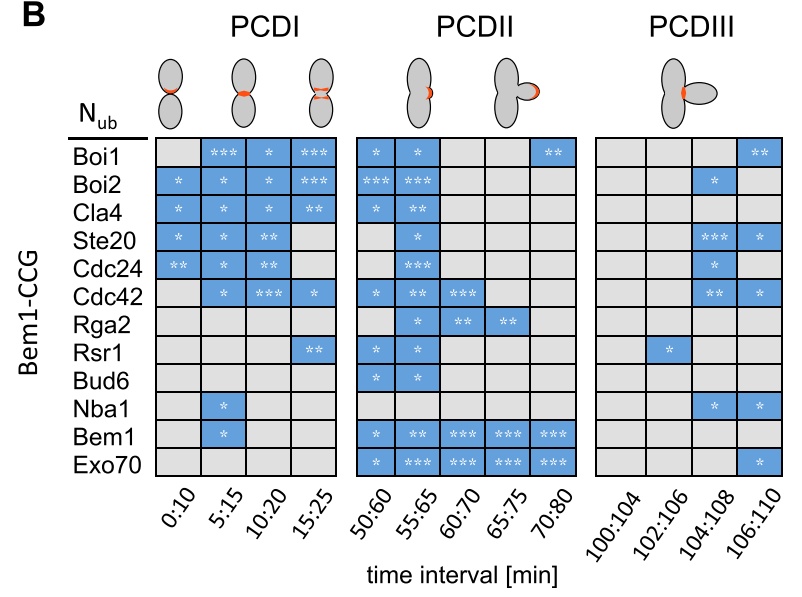

Figure 8. SPLIFF analysis of yeast zygotes formed by the fusion of a-cells expressing Bem1CCG and $\alpha$-cells expressing the indicated $\mathbf{N}_{\mathbf{u b}}$-fusions.

(A) Plotted are the conversions of Bem1CCG to Bem1CC (\%) over time. GFP- and mCherry fluorescence intensities were measured at sites of polarized Bem1 locations as indicated in red in the cartoons of the upper panel. Shown are fitted lines calculated from single-cell experiments. (B) Interaction profiles for Bem1. Blue boxes indicate a significant increase in conversion over the indicated time. For values below $70 \%$ of conversion, significant slopes have to be 1 (\% conversion/min) or larger. For values above $70 \%$, slopes have to be positive and significant. To be counted as interaction, the criteria must not be met by the negative control in the respective time window $(* * *=P$-value $<0.001$; ** $=P$-value $<0.01 ;{ }^{*}=P$-value $\left.<0.05\right)$.

Localizing Cdc24, stimulating its activity, and channeling Cdc42 to its effectors are separable activities of Bem1 that cooperate in the full-length protein to generate and read the gradient of active Cdc42 (Smith et al, 2013; Woods et al, 2015; Rapali et al, 2017). A temporal map of the interaction network of this complex might thus reveal where at a given time the activated $\mathrm{Cdc} 42$ is preferentially directed. SPLIFF is one of the very few techniques that allow analysis of temporal aspects of protein-protein interactions in living cells. The cleavage of GFP from the mCherry- $C_{u b}$-GFP coupled interaction partner gives a robust ratiometric output for interaction. However, to define the time point of interaction, one has to record the change of this value over time in single cells. The closer the chosen time points, the smaller the change and the less sensitive the measurement. To prove the significance of the observation, measurements have to be repeated in different cells at comparable positions of the cell cycle. In addition, the depletion of the uncleaved mCherry- $\mathrm{C}_{\mathrm{ub}}$-GFP fusion upon interaction reduces the maximal response during the later time points of the measurements. These features limit the sensitivity of the assay and sometimes blur the distinction between no or rarely occurring interactions. Despite these shortcomings, the application of SPLIFF provided a unique temporal interaction profile of the scaffold protein Bem1. As Bem1 links active Cdc42 to its effectors, Fig 10 summarizes the cellular flow of Cdc42 $2_{\text {TP }}$ through the cell cycle. During bud site formation and bud growth, Cdc42 is channeled directly to Exo70 and possibly from Boi1/2 to the other Cdc42-activated exocyst component Sec3. Boi1/2 were shown to recruit Bud6 and Bni1 to sites of active exocytosis (Glomb et al, 2020). The temporal formation of the Bem1Boi1/2-Bud6 complex might thus boost the Bni1-catalyzed actin filament formation and organization during bud site assembly and in small buds (Adams et al, 1990; Dong et al, 2003; Glomb et al, 2020). As the binding sites of Bem 1 for Boi1/2 and Exo70 do not overlap, a supercomplex that stimulates and coordinates actin assembly and vesicle fusion during bud assembly and early growth seems plausible (Adamo et al, 2001; Liu \& Novick, 2014; Kustermann et al, 2017; Glomb et al, 2020). This complex disassembles in large buds and does not detectably form during cytokinesis (Figs 8 and 10).

The PAKs Ste20 and Cla 4 contact Bem1 at the same site as Boi1/2 and form alternative, exclusive interaction states (Fig 10). The Cla4Bem1-Cdc42-Cdc24 and Ste20-Bem1-Cdc42-Cdc24 interaction states coexist with the Boi1/2-Bem1-Cdc42-Cdc24 interaction states except during abscission where only Ste20-Bem1-Cdc42-Cdc24 and Boi1/Boi2Bem1-Cdc42-Cdc24 are detectable (Figs 8 and 10). The persistent activation of Ste20 correlates with its role during cytokinesis and its early, CDK-independent activation in the next cell cycle (Moran et al, 2019).

The Boi1/2-Bem1-Cdc24 complex is anchored by Nba1 and additionally by Fir1 to the bud neck (Fig 7F). Fir1 is known to delay cell separation by inhibiting the cell separation kinase Cbk1 (Brace et al, 2019). NBA1 is synthetic lethal to a certain allele of the essential cytokinesis factor IQGAP (in yeast: IQG1), suggesting that Nba1 stimulates abscission (Tian et al, 2014). A better understanding of the functions of Nba1 and Fir1 might reveal how the Bem1/Cdc24 complex moderates cytokinesis.

The PAKs perform many other functions besides their roles during cytokinesis and bud formation (Drogen et al, 2000; Hofken \& Schiebel, 2002; Tanaka et al, 2014). The general Cdc42 sensitivity of cells lacking the Bem1-binding sites in STE2O and CLA4 indicates that the PAKBem1-Cdc42-Cdc24 interaction states are the operative units for many if not all PAK activities.

\section{Materials and Methods}

\section{Growth conditions and cultivation of yeast strains}

All yeast strains were derivatives of JD47, a descendant from a cross of the strains YPH500 and BBY45 (Sikorski \& Hieter, 1989; Bartel et al, 

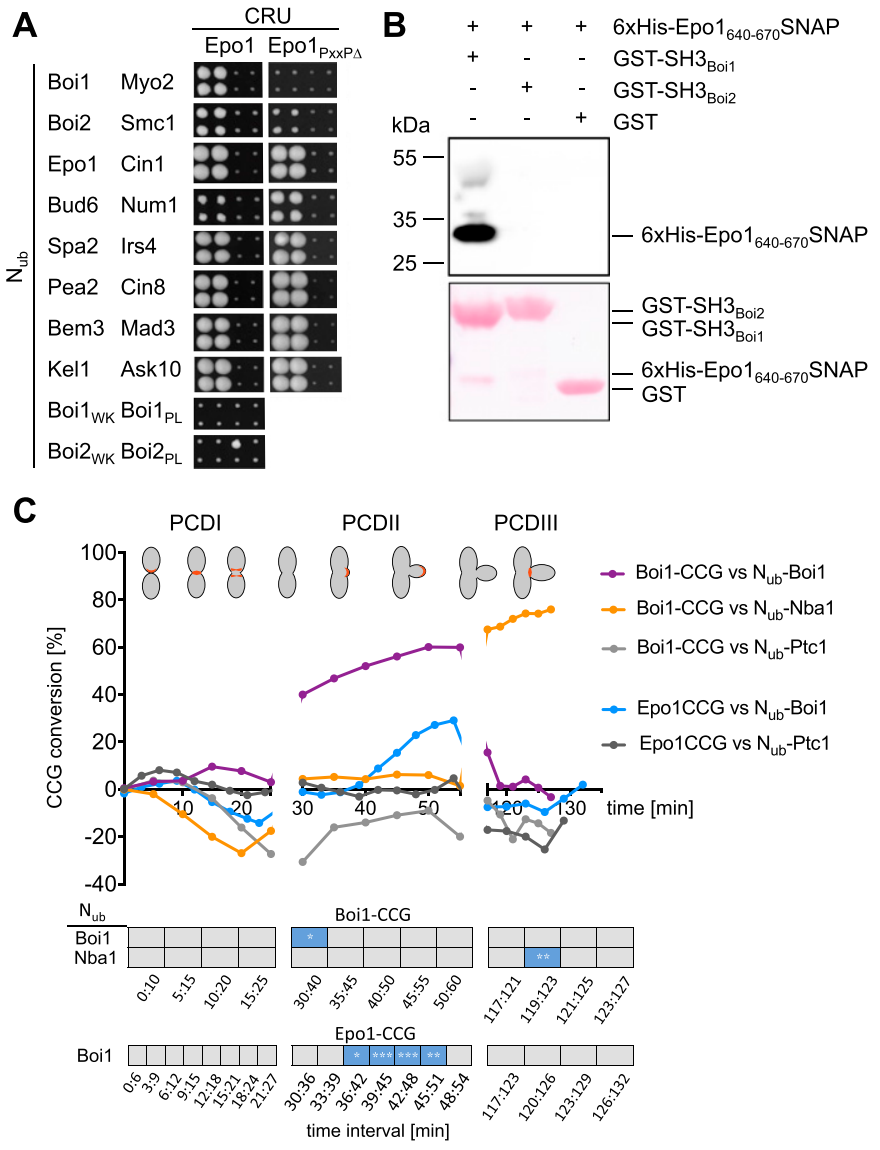

Figure 9. Epo1 interacts with Boi1 during budding.

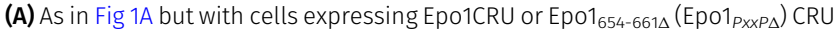
with the indicated $\mathrm{N}_{\mathrm{ub}}$ fusions. (B) Extracts containing a 6xHIS SNAP-tag fusion to Ep01640-670 were incubated with GST-Boi1-, GST-Boi2-, or GST-coupled beads. Glutathione-eluates were stained with Ponceau (lower panel), and anti-His antibodies (upper panel) after SDS-PAGE and transfer onto nitrocellulose.

(C) SPLIFF analysis: a-cells expressing Epo1CCG or Boi1CCG were mated with $\alpha$-cells expressing the indicated $\mathrm{N}_{\mathrm{ub}}$ fusions. Upper panel: The measured fluorescence intensities were processed and visualized as in Fig 8A. Significance of slopes of fitted lines across time intervals are shown in the lower panel $(* * *=P$-value $<$ $0.001 ;{ }^{* *}=P$-value $<0.01 ;{ }^{*}=P$-value $\left.<0.05\right)$

1990; Madura et al, 1993; Dohmen et al, 1995). Cultivation of yeast was performed in standard SD or YPD media at $30^{\circ} \mathrm{C}$ or the indicated temperatures as described (Dünkler et al, 2012). Media for split-ubiquitin interaction assay and selection for the loss of centromeric URA3-containing plasmids comprised $1 \mathrm{mg} / \mathrm{ml} \mathrm{5-}$ fluoro-orotic acid (5-FOA; Formedium).

\section{Construction of plasmids, gene fusions, and manipulations}

Construction of $\mathrm{N}_{\mathrm{ub}}$ and $\mathrm{C}_{\mathrm{ub}}$ gene fusions as well as GFP-, mCherry-, or mCherry- $C_{u b}$-RGFP (CCG) fusions was performed as described (Wittke et al, 1999; Dünkler et al, 2012; Moreno et al, 2013; Neller et al, 2015). Bem1CRU/-GFP/-CCG were constructed by genomic in-frame insertions of the GFP-, CRU-, or CCG modules behind the coding sequences of BEM1 or its alleles. In brief, a PCR fragment of the C-terminal region of the respective target gene lacking the stop codon was cloned via Eagl and Sall restriction sites in front of the CRU-, GFP-, mCherry-, or CCG-module on a pRS303, pRS304, or pRS306 vector (Sikorski \& Hieter, 1989). Plasmids were linearized using unique restriction sites within this sequence and transformed into yeast cells for integration into the genomic target ORF. Colony PCR with diagnostic primer combinations was used to verify the successful genomic integration. Centromeric plasmids expressing different fragments of BEM1 were obtained by ligation of PCR fragments spanning the respective region of $B E M 1$ behind the sequence of the $P_{\text {MET17 }}$-GFP module on the pRS313 vector (Table S3) (Sikorski \& Hieter, 1989). Mutations in the coding region of BEM1, STE20, CLA4, or BO/1 were obtained by overlap-extension PCR using plasmids containing the corresponding ORFs as templates.

Insertion of mutations into the BEM1, STE20, BOI1, or CLA4 loci were performed in yeast strains lacking the ORFs of the respective genes but still containing their $5^{\prime}$ and $3^{\prime}$ UTR sequences. Mutations were introduced in the respective genes on an integrative pRS vector containing the upand downstream sequences of the gene (Sikorski \& Hieter, 1989). Yeast strains lacking the corresponding ORF were then transformed with the mutated gene on the integrative vector linearized in the promoter sequence of the gene. Successful integration was verified by diagnostic PCR.

Alternatively, insertion of genomic mutations was achieved by CRISPR/Cas9 (Laughery et al, 2015). To introduce the mutations at the chosen sites, guideRNA sequences were cloned into $\mathrm{PML}$ plasmids and co-transformed with oligonucleotides harboring the desired mutations. Successful manipulations were verified by PCR product sequencing of the respective genomic ORFs. Details of the introduced mutations are listed in Table S4.

In certain strains, the native promoter sequence was replaced by $P_{M E T 17}$ through recombination with a PCR fragment generated from PYM-N35 and primers containing sequences identical to the respective genomic locations at their $5^{\prime}$ ends (Janke et al, 2004). GST fusions were obtained by placing the ORF of the respective gene or gene fragment in frame behind the Escherichia coli GST sequence on the pGEX-2T plasmid (GE Healthcare) using BamHI and EcoRI restriction sites. Fusions to the human 06-Alkyl-DNA transferase (SNAP-tag; New England Biolabs) were expressed from plasmid pAGT-Xpress, a pET-15b derivative (Schneider et al, 2013). Gene fragments were inserted in frame into a multi-cloning site located between the upstream 6xHIS-tagcoding sequence and the downstream SNAP-tag-coding sequence. The 6xHIS-tag fusions were obtained by placing the ORF of the respective gene or gene fragment behind the E. coli 6 XHIS-tag sequence on the previously constructed pAC plasmid (Schneider et al, 2013).

Gene deletions were performed by one step PCR-based homologous recombination using pFA6a natNT2, pFA6a hphNT1, pFA6a kanMX6, pFA6a CMLEU2, and pFA6a HISMX6 as templates (Bähler et al, 1998; Longtine et al, 1998; Janke et al, 2004; Schaub et al, 2006). Lists of plasmids and yeast strains used in this study can be found in Tables S3 and S4 of the supplemental information. Plasmid maps can be obtained upon request.

\section{Split-Ub interaction analysis}

Bem1 was fused to the C-terminal half of Ubiquitin followed by Ura3 carrying an arginine at its $\mathrm{N}$ terminus to create Bem1- $\mathrm{C}_{\mathrm{ub}}-\mathrm{RU}$ ra3 (Bem1CRU). Upon co-expression of a binding partner of Bem1 carrying the $\mathrm{N}$-terminal half of $\mathrm{Ub}\left(\mathrm{N}_{\mathrm{ub}}-\mathrm{X}\right)$ at its $\mathrm{N}$ terminus, $\mathrm{N}_{\mathrm{ub}}$ and $\mathrm{C}_{\mathrm{ub}}$ are brought into close proximity and the native-like Ubiquitin is reconstituted from its two halves. Ub-specific proteases cleave off the 

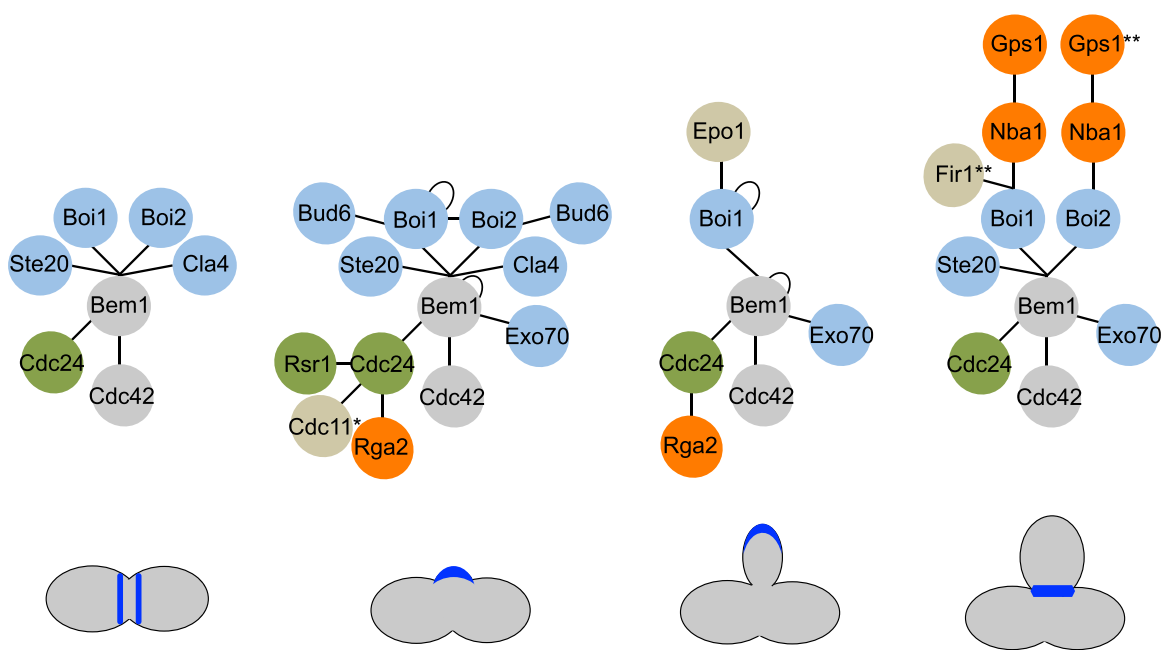

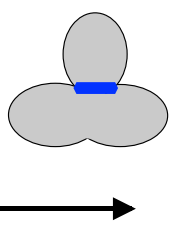

Figure 10. Interaction networks of Bem1 during PCDI (10-20 min), early and late PCDII (50-55 min, 60-80 min), and PCDIII (104-110 min).

Green color indicates proteins that promote, orange color indicates proteins that reduce active $\mathrm{Cdc42}$. Blue color indicates effectors of $\mathrm{Cdc} 42$ or proteins that bind to effectors (Bud6-Bni1). Epo1 binds to the same site of Boi1 as Nba1 or Fir1 but at a different cell cycle phase. *The time point of interaction between Bem1Cdc24-Cdc11 was obtained from a previous study (Chollet et al, 2020). ${ }^{* *}$ The time point of Fir1- and Gps1 binding to Bem1 were indirectly derived through their effects on Bem1 localization (Fig 7).

RUra3 module from $\mathrm{C}_{\mathrm{ub}}$ and the exposed arginine initiates the degradation of RUra3. As a consequence, cells have no Ura3 activity and do not convert 5-FOA in the toxic 5-fluoro-uracil. The growth of cells on media containing 5-FOA is thus taken as evidence of interaction between the $\mathrm{C}_{\mathrm{ub}}$ - and $\mathrm{N}_{\mathrm{ub}}$-coupled fusion protein (Johnsson \& Varshavsky, 1994; Wittke et al, 1999).

\section{Array analysis}

A library of 548 different $\alpha$-strains each expressing a different $\mathrm{N}_{\mathrm{ub}}$ fusion were mated with a BEM1- $C_{u b}-R-U R A 3$ (Bem1CRU), BEM1 ${ }_{W K}-C_{u b}-R$-URA3 (Bem1 ${ }_{W K} C R U$ ), or $B E M 1_{P B 1 \Delta}-C_{u b}-R-U R A 3$ (Bem1 $1_{P B 1 \Delta} C R U$ ) expressing a-strain. Diploids were transferred as independent quadruplets on SD media containing $1 \mathrm{mg} / \mathrm{ml}$ 5-FOA. Expressions of the $\mathrm{N}_{\mathrm{ub}}$ fusions were under control of the copper inducible $P_{\text {CUP1-promoter. Media contained }}$ different concentrations of copper to adjust the amount of the $\mathrm{N}_{\mathrm{ub}}$ fusions (Dünkler et al, 2012).

\section{Individual Split-Ub interaction analysis}

$\mathrm{CRU}$ and $\mathrm{N}_{\mathrm{ub}}$ expressing strains were mated or co-expressed in haploid cells and spotted onto the medium containing $1 \mathrm{mg} / \mathrm{ml}$ FOA and different concentrations of copper in four 10 -fold serial dilutions starting from $\mathrm{OD}_{600}=1$. Growth at $30^{\circ} \mathrm{C}$ was recorded every day for $3-5 \mathrm{~d}$.

\section{Complementation analysis}

bem1 $1 \triangle$ cells expressing BEM1 from a URA3-containing centromeric vector and fragments of $B E M 1$ from an HIS3-containing vector were either streaked directly or spotted as 10-fold serial dilutions onto SD His ${ }^{-}$media containing $1 \mathrm{mg} / \mathrm{ml}$ 5-FOA. As 5-FOA is converted by Ura3 to the toxic 5-fluoro-uracil, the medium counter-selects against the presence of the BEM1-expressing URA3 vector.

\section{Mating efficiency}

Saturated cultures of JD47 cells containing the respective allele of STE20 and expressing Gic2 ${ }_{\mathrm{PBD}}$ from a centromeric plasmid under the control of a $P_{\text {MET17 }}$ promoter and JD53 cells carrying a Kanamycintagged PTC1 gene and expressing Gic2 $2_{\text {PBD }}$ were resuspended in media containing no or $70 \mu \mathrm{m}$ methionine and grown for $6 \mathrm{~h}$ at $30^{\circ} \mathrm{C}$. Cells were adjusted to an $\mathrm{OD}_{600}$ of 1 and equal amounts of JD53 and JD47 cells mixed and incubated for $4 \mathrm{~h}$ at $30^{\circ} \mathrm{C}$. Cells were diluted $1 / 20$ and $250 \mu \mathrm{l}$ of each mating were spread on media selecting for diploids. Colony numbers were counted after $2 \mathrm{~d}$ at $30^{\circ} \mathrm{C}$.

\section{Preparation of yeast cell extracts}

Exponentially grown yeast cell cultures were pelleted and resuspended in yeast extraction buffer (50 mM Hepes, $150 \mathrm{mM} \mathrm{NaCl}$, and 1 mM EDTA) with $1 \times$ protease inhibitor cocktail (Roche Diagnostics). Cells were lysed by vortexing them together with glass beads (threefold amount of glass beads and extraction buffer to pellet weight) 12 times for 1 min interrupted by short incubations on ice. The obtained yeast cell extracts were clarified by centrifugation at $16,000 \mathrm{~g}$ for $20 \mathrm{~min}$ at $4^{\circ} \mathrm{C}$.

\section{Recombinant protein expression and purification from $E$. coli}

All proteins were expressed in E. coli BL21DE3 cells. GST-Bud6 $6_{1-320}$ was expressed at $30^{\circ} \mathrm{C}$ for $5 \mathrm{~h}$ in LB medium after induction with 1 mM IPTG. GST fusions to SH3 domains of Boi1 and Boi2 and 6xHis$\mathrm{Nba}_{202-289}-\mathrm{SNAP}$ were expressed at $18^{\circ} \mathrm{C}$ in the SB medium for $20 \mathrm{~h}$ after induction with $0.1 \mathrm{mM}$ IPTG. Cells were pelleted, washed once with PBS, and stored at $-80^{\circ} \mathrm{C}$ until lysis. All subsequent purifications were carried out on an Äkta Purifier chromatography device (GE Healthcare). Cells expressing GST fusion proteins were resuspended in PBS containing protease inhibitor cocktail (Roche Diagnostics) and lysed by lysozyme treatment $(1 \mathrm{mg} / \mathrm{ml}, 30 \mathrm{~min}$ on ice), followed by sonication with a Bandelin Sonopuls HD 2070 (Reichmann Industries service). Extracts were clarified by centrifugation at $40,000 \mathrm{~g}$ for $10 \mathrm{~min}$ at $4^{\circ} \mathrm{C}$, and the proteins were purified using a 5-ml GSTrap column (GE Healthcare) and subsequent size exclusion chromatography on a Superdex 200 16/60 column versus 
HBSEP buffer ( $10 \mathrm{mM}$ Hepes, $150 \mathrm{mM} \mathrm{NaCl}, 3 \mathrm{mM}$ EDTA, and 0.05\% Tween 20, pH 7.4). Purified protein was concentrated and stored on ice.

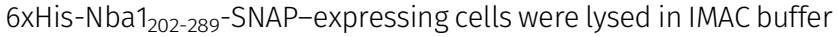
(50 $\mathrm{mM} \mathrm{KH}_{2} \mathrm{PO}_{4}, 300 \mathrm{mM} \mathrm{NaCl}$, and $20 \mathrm{mM}$ imidazole containing protease inhibitor cocktail) as described above, and enriched protein was obtained by imidazole gradient elution from a 5-ml HisTrap HP column (GE Healthcare), followed by size-exclusion chromatography.

\section{GST pull-down assay}

GST-tagged proteins were immobilized on Glutathione Sepharose beads (GE Healthcare) directly from E. coli extracts. After 1-h incubation at $4^{\circ} \mathrm{C}$ with either yeast extracts or purified proteins under rotation at $4^{\circ} \mathrm{C}$, the beads were washed three times with the respective buffer. Bound material was eluted with GST elution buffer (50 mM Tris and $20 \mathrm{mM}$ reduced glutathione) and analyzed by SDS-PAGE followed by Coomassie staining and immunoblotting with anti-His (dilution: 1:5,000; Sigma Aldrich), or anti-GFP-antibodies (dilution 1:1,000; Roche Diagnostics).

\section{Surface plasmon resonance measurements}

Binding affinities were measured using purified and immobilized GSTSH3 ${ }_{\text {Boi1 }}$ or GST-SH3 ${ }_{\text {Boi2 }}$ as ligands on an anti-GST chip on a Biacore X100 device (GE Healthcare). HBSEP buffer was used as the running buffer in all experiments. The chip was prepared by covalent coupling of an antiGST antibody (GE Healthcare) as capture molecule to the dextran surface of both flow cells of a CM5 chip (GE Healthcare) using an amine coupling kit (GE Healthcare). GST-tagged ligand proteins were captured on the detection flow cell of the chip, and free GST was captured on the reference flow cell. Purified 6xHis-NBA1 $202-289-S N A P$ as an analyte molecule was prepared in suitable concentrations in running buffer and kinetics were measured with constant flow over the previously prepared chip. Regeneration after each cycle was achieved by a 20-s injection pulse with $10 \mathrm{mM}$ glycine, $\mathrm{pH}$ 2.0. The equilibrium binding constant $K_{D}$ was subsequently determined by the X100 evaluation software using background subtracted sensograms. All measurements were performed at least as triplicate.

\section{Fluorescence microscopy}

For microscopic inspection, yeast cells were grown overnight in SD medium, diluted 1:8 in 3-4 $\mathrm{ml}$ fresh SD medium, and grown for 3-6 $\mathrm{h}$ at $30^{\circ} \mathrm{C}$ to mid-log phase. About $1 \mathrm{ml}$ culture was spun down, and the cell pellet resuspended in 20-50- $\mu \mathrm{l}$ residual medium. $3 \mu \mathrm{l}$ was spotted onto a microscope slide, and the cells were immobilized with a coverslip and inspected under the microscope. For time-resolved imaging, $3 \mu \mathrm{l}$ of prepared cell suspension was mounted on an SD-agarose pad $(1.7 \%$ agarose), embedded in a customized glass slide, and sealed by a coverslip fixed by parafilm stripes. Imaging was started after 15-30 min recovery at $30^{\circ} \mathrm{C}$. SPLIFF and other time-lapse experiments were observed under a wide-field fluorescence microscope system (DeltaVision; GE Healthcare) provided with a Olympus IX71 microscope, a steady-state heating chamber, a CoolSNAP HQ2 and Cascadell512-CCD camera both by Photometrics, a U Plan S Apochromat $100 \AA$ 1.4 NA oil $\infty / 0.17 /$ FN26.5 objective and a Photofluor LM-75 halogen lamp. Images were visualized using softWoRx software (GE Healthcare) and adapted $z$ series at $30^{\circ} \mathrm{C}$.
Exposure time was adapted to the intensity of GFP and mCherry signal for every fluorescently labeled protein to reduce bleaching and phototoxicity. Further analyses used an Axio Observer spinning-disk confocal microscope (Zeiss), equipped with an Evolve512 EMCCD camera (Photometrics), a Plan-Apochromat $63 \AA$ / 1.4 oil DIC objective, and 488-and 561-nm diode lasers (Zeiss). Images were analyzed with the ZEN2 software (Zeiss).

\section{Quantitative analysis of microscopy data and SPLIFF measurements}

Microscopy data were processed and analyzed using ImageJ64 1.49 software. For standard fluorescence signal quantification, three regions of interest (ROIs) were determined, first the signal of interest (e.g., tip, bud neck), second a region in the cytosol, and third a randomly chosen position outside of the cell (background). The mean gray values of each ROI ( $I_{\text {fluorescence, }} I_{\text {cytosol, }}$ and $\left.I_{\text {background }}\right)$ were quantified after z-projection. To compare the fluorescence signals of a protein in certain strains, the relative fluorescence ( $\left.I_{\text {relative }}\right)$ signal of the protein was calculated after subtraction of the background.

$$
I_{\text {relative }}=I_{\text {fluorescence }}-I_{\text {background }} / I_{\text {cytosol }}-I_{\text {background }}
$$

\section{SPLIFF analysis}

SPLIFF analysis for temporal and spatial characteristics of Bem1-, Boi1-, and Epo1-CCG interactions was performed as described (Moreno et al, 2013; Dunkler et al, 2015). a-cells expressing the $P_{\text {MET17 }}$ promotercontrolled CCG fusions were grown in SD medium without methionine and mixed with MAT $\alpha$ cells expressing $\mathrm{N}_{\mathrm{ub}}-\mathrm{HA}$ fusions either under their

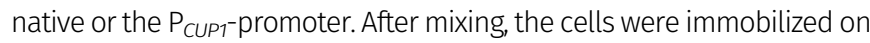
an SD agarose pad and mating-induced interaction was monitored by three channel z-stack $(5 \times 0.6 \mu \mathrm{m})$ microscopy every 2,3 , or 5 min. $z$-slices with fluorescence signals were projected by SUM projection. The FI of mCherry and GFP channels were determined by integrated density measurements of the ROI and a region within the cytosol. For each time point and channel, the intracellular background was subtracted from the localized signal to obtain the localized fluorescence intensity ( $\mathrm{FI}_{\text {red }}$ and $\left.\mathrm{Fl}_{\text {green }}\right)$. The values were normalized to the time point before cell fusion. The resulting relative fluorescence intensity $\mathrm{RFI}(\mathrm{t})$ was then used to calculate the conversion $\mathrm{FD}(\mathrm{t})$ :

$$
F D(t)=R F I_{\text {red }}-R F I_{\text {green }} / R F I_{\text {red }}
$$

$\mathrm{FD}(\mathrm{t})$ as a readout of CCG- to CC conversion describes its temporal progress in percent. Excel was used for initial calculations.

\section{Regression and slope estimation of SPLIFF analysis}

To test significance of increment of percent conversion over time, the non-parametric local regression (loess) (R Core Team, 2019) was first fitted by taking all biological replicates across the entire time window. The fitted line was then used for the generalized additive model (Hastie, 2019). For the generalized additive model, two time intervals with one time point sliding window were used to estimate the slope of rate of change of percent of conversion. Positive slopes with a $P$-value cutoff of 0.05 were considered as statistically significant. 


\section{FRAP experiments}

FRAP experiments were performed as described elsewhere with an iMIC digital microscope with a 60× objective (Till Photonics) at RT (Phair et al, 2004). Pictures were acquired with a series of five $z$-slices each separated by $0.5 \mu \mathrm{M}$. Four images were taken before the ROI was bleached with $100 \%$ laser power, a dwell time of $1.2 \mathrm{~s} / \mu \mathrm{m}^{2}$, a line overlap of $42 \%$, and an experimental loop count of 10-20. Pictures were taken at a constant time interval of $0.9 \mathrm{~s}$ after bleaching except $\mathrm{SH} 3_{\text {Boi1 }}$-GFP where signal recovery was measured each $0.25 \mathrm{~s}$ in a single z-layer. Initial z-slice projection and fluorescence quantification was performed with the software iMIC Offline analysis. Alternatively, an Axio Observer spinning-disc confocal microscope (Zeiss), equipped with a Zeiss Plan-Apochromat $63 \AA$ ̊ /1.4 oil DIC objective, a 488-nm diode lasers, and an UGA-42 photo-manipulation system was used (Rapp OptoElectronic). Initial signal measurements were Image) based. Subsequently, all data sets were double-normalized using Excel. The software Prism 6.0 (GraphPad) was used for the fitting of the double-normalized data to a one-phase association curve.

\section{Statistical evaluation}

GraphPad Prism was applied for statistical data evaluation. The distributions of the data sets were analyzed by the D'Agostino and Pearson normality test. $t$ tests were used to analyze data following a normal distribution, whereas Mann-Whitney $U$ tests were used for data that did not pass these criteria. The one-way ANOVA or the Kruskal-Wallis ANOVA tests were used to compare data sets from more than two groups.

\section{Supplementary Information}

Supplementary Information is available at https://doi.org/10.26508/lsa. 202000813.

\section{Acknowledgements}

We thank S Timmermanns and N Schmidt for technical assistance. The work was funded by grants from the Deutsche Forschungsgemeinschaft to $\mathrm{N}$ Johnsson (Jo 187/5-2,-3; Jo 187/9-1).

\section{Author Contributions}

S Grinhagens: conceptualization, investigation, and visualization. A Dünkler: conceptualization, supervision, investigation, visualization, and methodology.

Y Wu: conceptualization and investigation.

L Rieger: investigation.

P Brenner: investigation.

T Gronemeyer: investigation.

MA Mulaw: formal analysis and methodology.

N Johnsson: conceptualization, supervision, funding acquisition, investigation, and writing-original draft.

\section{Conflict of Interest Statement}

The authors declare that they have no conflict of interest.

\section{References}

Adamo JE, Moskow JJ, Gladfelter AS, Viterbo D, Lew DJ, Brennwald PJ (2001) Yeast Cdc42 functions at a late step in exocytosis, specifically during polarized growth of the emerging bud. I Cell Biol 155: 581-592. doi:10.1083/jcb.200106065

Adams AE, Johnson DI, Longnecker RM, Sloat BF, Pringle JR (1990) CDC42 and $\mathrm{CDC} 43$, two additional genes involved in budding and the establishment of cell polarity in the yeast Saccharomyces cerevisiae. I Cell Biol 111: 131-142. doi:10.1083/jcb.111.1.131

Atkins BD, Yoshida S, Pellman D (2008) Symmetry breaking: Scaffold plays matchmaker for polarity signaling proteins. Curr Biol 18: R1130-R1132. doi:10.1016/j.cub.2008.11.005

Atkins BD, Yoshida S, Saito K, Wu CF, Lew DJ, Pellman D (2013) Inhibition of Cdc42 during mitotic exit is required for cytokinesis. J Cell Biol 202: 231-240. doi:10.1083/jcb.201301090

Bähler J, Wu JQ, Longtine MS, Shah NG, McKenzie A 3rd, Steever AB, Wach A, Philippsen P, Pringle JR (1998) Heterologous modules for efficient and versatile PCRbased gene targeting in Schizosaccharomyces pombe. Yeast 14: 943-951. doi:10.1002/(sici)1097-0061(199807)14:10<943.:aid-yea292>3.0.co;2-y

Bartel B, Wunning I, Varshavsky A (1990) The recognition component of the $\mathrm{N}$ end rule pathway. EMBO / 9: 3179-3189. doi:10.1002/j.14602075.1990.tb07516.x

Bender L, Lo HS, Lee H, Kokojan V, Peterson V, Bender A (1996) Associations among $\mathrm{PH}$ and $\mathrm{SH} 3$ domain-containing proteins and Rho-type GTPases in yeast. / Cell Biol 133: 879-894. doi:10.1083/jcb.133.4.879

Bhattacharyya RP, Remenyi A, Good MC, Bashor C), Falick AM, Lim WA (2006) The Ste5 scaffold allosterically modulates signaling output of the yeast mating pathway. Science 311: 822-826. doi:10.1126/science.1120941

Bi E, Park HO (2012) Cell polarization and cytokinesis in budding yeast. Genetics 191: 347-387. doi:10.1534/genetics.111.132886

Bose I, Irazoqui JE, Moskow JJ, Bardes ES, Zyla TR, Lew DJ (2001) Assembly of scaffold-mediated complexes containing Cdc42p, the exchange factor Cdc24p, and the effector Cla4p required for cell cycle-regulated phosphorylation of Cdc24p. J Biol Chem 276: 7176-7186. doi:10.1074/ jbc.m010546200

Brace JL, Doerfler MD, Weiss EL (2019) A cell separation checkpoint that enforces the proper order of late cytokinetic events. I Cell Biol 218: 150-170. doi:10.1083/jcb.201805100

Brown JL, Jaquenoud M, Gulli MP, Chant J, Peter M (1997) Novel Cdc42-binding proteins Gic1 and Gic2 control cell polarity in yeast. Genes Dev 11: 2972-2982. doi:10.1101/gad.11.22.2972

Butty AC, Perrinjaquet N, Petit A, Jaquenoud M, Segall JE, Hofmann K, Zwahlen C, Peter M (2002) A positive feedback loop stabilizes the guaninenucleotide exchange factor $\mathrm{Cdc} 24$ at sites of polarization. EMBO I 21: 1565-1576. doi:10.1093/emboj/21.7.1565

Chang E, Bartholomeusz G, Pimental R, Chen J, Lai H, Wang L, Yang P, Marcus S (1999) Direct binding and in vivo regulation of the fission yeast p21activated kinase shk1 by the $\mathrm{SH} 3$ domain protein scd2. Mol Cell Biol 19: 8066-8074. doi:10.1128/mcb.19.12.8066

Chenevert J, Corrado K, Bender A, Pringle J, Herskowitz I (1992) A yeast gene (BEM1) necessary for cell polarization whose product contains two SH3 domains. Nature 356: 77-79. doi:10.1038/356077a0

Chiou JG, Balasubramanian MK, Lew DJ (2017) Cell polarity in yeast. Annu Rev Cell Dev Biol 33: 77-101. doi:10.1146/annurev-cellbio-100616-060856

Chollet J, Dunkler A, Bauerle A, Vivero-Pol L, Mulaw MA, Gronemeyer T, Johnsson N (2020) Cdc24 interacts with septins to create a positive feedback loop during bud site assembly in yeast. I Cell Sci 133: jcs240283. doi:10.1242/jcs.240283

Cvrckova F, De Virgilio C, Manser E, Pringle JR, Nasmyth K (1995) Ste20-like protein kinases are required for normal localization of cell growth 
and for cytokinesis in budding yeast. Genes Dev 9: 1817-1830. doi:10.1101/gad.9.15.1817

Dohmen RJ, Stappen R, McGrath JP, Forrova H, Kolarov J, Goffeau A, Varshavsky A (1995) An essential yeast gene encoding a homolog of ubiquitin-activating enzyme. J Biol Chem 270: 18099-18109. doi:10.1074/jbc.270.30.18099

Dong Y, Pruyne D, Bretscher A (2003) Formin-dependent actin assembly is regulated by distinct modes of Rho signaling in yeast. I Cell Biol 161: 1081-1092. doi:10.1083/jcb.200212040

Dowell RD, Ryan O, Jansen A, Cheung D, Agarwala S, Danford T, Bernstein DA, Rolfe PA, Heisler LE, Chin B, et al (2010) Genotype to phenotype: A complex problem. Science 328: 469. doi:10.1126/science.1189015

Drogen F, O'Rourke SM, Stucke VM, Jaquenoud M, Neiman AM, Peter M (2000) Phosphorylation of the MEKK Ste11p by the PAK-like kinase Ste20p is required for MAP kinase signaling in vivo. Curr Biol 10: 630-639. doi:10.1016/s0960-9822(00)00511-X

Dünkler A, Müller J, Johnsson N (2012) Detecting protein-protein interactions with the split-ubiquitin sensor. Methods Mol Biol 786: 115-130. doi:10.1007/978-1-61779-292-2_7

Dunkler A, Rosler R, Kestler HA, Moreno-Andres D, Johnsson N (2015) SPLIFF: A single-cell method to map protein-protein interactions in time and space. Methods Mol Biol 1346: 151-168. doi:10.1007/978-1-4939-2987-0_11

Evangelista M, Blundell K, Longtine MS, Chow CJ, Adames N, Pringle JR, Peter M, Boone C (1997) Bni1p, a yeast formin linking cdc42p and the actin cytoskeleton during polarized morphogenesis. Science 276: 118-122. doi:10.1126/science. 276.5309 .118

Glomb O, Wu Y, Rieger L, Ruthnick D, Mulaw MA, Johnsson N (2020) The cell polarity proteins Boi1 and Boi2 direct an actin nucleation complex to sites of exocytosis in Saccharomyces cerevisiae. I Cell Sci 133: jcs237982. doi:10.1242/jcs.237982

Gorelik M, Davidson AR (2012) Distinct peptide binding specificities of Src homology 3 ( $\mathrm{SH} 3$ ) protein domains can be determined by modulation of local energetics across the binding interface. J Biol Chem 287: 9168-9177. doi:10.1074/jbc.m111.330753

Graziano BR, DuPage AG, Michelot A, Breitsprecher D, Moseley JB, Sagot I, Blanchoin L, Goode BL (2011) Mechanism and cellular function of Bud6 as an actin nucleation-promoting factor. Mol Biol Cell 22: 4016-4028. doi:10.1091/mbc.e11-05-0404

Graziano BR, Jonasson EM, Pullen JG, Gould CJ, Goode BL (2013) Ligandinduced activation of a formin-NPF pair leads to collaborative actin nucleation. J Cell Biol 201: 595-611. doi:10.1083/jcb.201212059

Gulli MP, Jaquenoud M, Shimada Y, Niederhauser G, Wiget P, Peter M (2000) Phosphorylation of the $\mathrm{Cdc42}$ exchange factor $\mathrm{Cdc} 24$ by the PAK-like kinase Cla4 may regulate polarized growth in yeast. Mol Cell 6: 1155-1167. doi:10.1016/s1097-2765(00)00113-1

Hallett MA, Lo HS, Bender A (2002) Probing the importance and potential roles of the binding of the $\mathrm{PH}$-domain protein Boi1 to acidic phospholipids. BMC Cell Biol 3: 16. doi:10.1186/1471-2121-3-16

Hastie T (2019) GAM: Generalized additive models. R package version 1.16.1. https: / / CRAN.R-project.org/package=gam.

Hofken T, Schiebel E (2002) A role for cell polarity proteins in mitotic exit. EMBO J 21: 4851-4862. doi:10.1093/emboj/cdf481

Holly SP, Blumer KJ (1999) PAK-family kinases regulate cell and actin polarization throughout the cell cycle of Saccharomyces cerevisiae. J Cell Biol 147: 845-856. doi:10.1083/jcb.147.4.845

Howell AS, Lew DJ (2012) Morphogenesis and the cell cycle. Genetics 190: 51-77. doi:10.1534/genetics.111.128314

Hruby A, Zapatka M, Heucke S, Rieger L, Wu Y, Nussbaumer U, Timmermann S, Dünkler A, Johnsson N (2011) A constraint network of interactions: Protein-protein interaction analysis of the yeast type II phosphatase Ptc1p and its adaptor protein Nbp2p. J Cell Sci 124: 35-46. doi:10.1242/ jcs.077065
Irazoqui JE, Gladfelter AS, Lew DJ (2003) Scaffold-mediated symmetry breaking by Cdc42p. Nat Cell Biol 5: 1062-1070. doi:10.1038/ncb1068

Janke C, Magiera MM, Rathfelder N, Taxis C, Reber S, Maekawa H, MorenoBorchart A, Doenges G, Schwob E, Schiebel E, et al (2004) A versatile toolbox for PCR-based tagging of yeast genes: New fluorescent proteins, more markers and promoter substitution cassettes. Yeast 21: 947-962. doi:10.1002/yea.1142

Johnsson N (2014) Analyzing protein-protein interactions in the postinteractomic era. Are we ready for the endgame? Biochem Biophys Res Commun 445: 739-745. doi:10.1016/j.bbrc.2014.02.023

Johnsson N, Varshavsky A (1994) Split ubiquitin as a sensor of protein interactions in vivo. Proc Natl Acad Sci U S A 91: 10340-10344. doi:10.1073/pnas.91.22.10340

Knaus M, Pelli-Gulli MP, van Drogen F, Springer S, Jaquenoud M, Peter M (2007) Phosphorylation of Bem2p and Bem3p may contribute to local activation of Cdc42p at bud emergence. EMBO J 26: 4501-4513. doi:10.1038/sj.emboj.7601873

Kozubowski L, Saito K, Johnson JM, Howell AS, Zyla TR, Lew DJ (2008) Symmetry-breaking polarization driven by a Cdc42p GEF-PAK complex. Curr Biol 18: 1719-1726. doi:10.1016/j.cub.2008.09.060

Kuo CC, Savage NS, Chen H, Wu CF, Zyla TR, Lew DJ (2014) Inhibitory GEF phosphorylation provides negative feedback in the yeast polarity circuit. Curr Biol 24: 753-759. doi:10.1016/j.cub.2014.02.024

Kustermann J, Wu Y, Rieger L, Dedden D, Phan T, Walther P, Dunkler A, Johnsson N (2017) The cell polarity proteins Boi1p and Boi2p stimulate vesicle fusion at the plasma membrane of yeast cells. J Cell Sci 130: 2996-3008. doi:10.1242/jcs.206334

Laan L, Koschwanez JH, Murray AW (2015) Evolutionary adaptation after crippling cell polarization follows reproducible trajectories. Elife 4: e09638. doi:10.7554/elife.09638

Lamson RE, Winters MJ, Pryciak PM (2002) Cdc42 regulation of kinase activity and signaling by the yeast p21-activated kinase Ste20. Mol Cell Biol 22 2939-2951. doi:10.1128/mcb.22.9.2939-2951.2002

Larson SM, Davidson AR (2000) The identification of conserved interactions within the $\mathrm{SH} 3$ domain by alignment of sequences and structures. Protein Sci 9: 2170-2180. doi:10.1110/ps.9.11.2170

Laughery MF, Hunter T, Brown A, Hoopes J, Ostbye T, Shumaker T, Wyrick JJ (2015) New vectors for simple and streamlined CRISPR-Cas9 genome editing in Saccharomyces cerevisiae. Yeast 32: 711-720. doi:10.1002/ yea.3098

Leberer E, Wu C, Leeuw T, Fourest-Lieuvin A, Segall JE, Thomas DY (1997) Functional characterization of the $\mathrm{Cdc42p}$ binding domain of yeast Ste20p protein kinase. EMBO J 16: 83-97. doi:10.1093/emboj/ 16.1 .83

Li R, Wedlich-Soldner R (2009) Bem1 complexes and the complexity of yeast cell polarization. Curr Biol 19: R194-R195. doi:10.1016/j.cub.2009.01.020

Liu D, Novick P (2014) Bem1p contributes to secretory pathway polarization through a direct interaction with Exo70p. I Cell Biol 207: 59-72. doi:10.1083/jcb.201404122

Longtine MS, McKenzie A 3rd, Demarini DJ, Shah NG, Wach A, Brachat A, Philippsen P, Pringle JR (1998) Additional modules for versatile and economical PCR-based gene deletion and modification in Saccharomyces cerevisiae. Yeast 14: 953-961. doi:10.1002/(sici)10970061(199807)14:10<953::aid-yea293>3.0.c0;2-u

Lyons DM, Mahanty SK, Choi KY, Manandhar M, Elion EA (1996) The SH3domain protein Bem1 coordinates mitogen-activated protein kinase cascade activation with cell cycle control in Saccharomyces cerevisiae. Mol Cell Biol 16: 4095-4106. doi:10.1128/mcb.16.8.4095

Madura K, Dohmen RJ, Varshavsky A (1993) N-recognin/Ubc2 interactions in the $\mathrm{N}$-end rule pathway. J Biol Chem 268: 12046-12054.

Masgrau A, Battola A, Sanmartin T, Pryszcz LP, Gabaldon T, Mendoza M (2017) Distinct roles of the polarity factors Boil and Boi2 in the control of 
exocytosis and abscission in budding yeast. Mol Biol Cell 28: 3082-3094. doi:10.1091/mbc.e17-06-0404

Matsui Y, Matsui R, Akada R, Toh-e A (1996) Yeast src homology region 3 domain-binding proteins involved in bud formation. J Cell Biol 133: 865-878. doi:10.1083/jcb.133.4.865

Meca J, Massoni-Laporte A, Martinez D, Sartorel E, Loquet A, Habenstein B, McCusker D (2019) Avidity-driven polarity establishment via multivalent lipid-GTPase module interactions. EMBO J 38: e99652. doi:10.15252/embj.201899652

Meitinger F, Khmelinskii A, Morlot S, Kurtulmus B, Palani S, Andres-Pons A, Hub B, Knop M, Charvin G, Pereira G (2014) A memory system of negative polarity cues prevents replicative aging. Cell 159: 1056-1069. doi:10.1016/j.cell.2014.10.014

Moran KD, Kang H, Araujo AV, Zyla TR, Saito K, Tsygankov D, Lew DJ (2019) Cellcycle control of cell polarity in yeast. J Cell Biol 218: 171-189. doi:10.1083/jcb.201806196

Moreno D, Neller J, Kestler HA, Kraus J, Dünkler A, Johnsson N (2013) A fluorescent reporter for mapping cellular protein-protein interactions in time and space. Mol Syst Biol 9: 647. doi:10.1038/msb.2013.3

Mukherjee D, Sen A, Boettner DR, Fairn GD, Schlam D, Bonilla Valentin FJ, Michael McCaffery J, Hazbun T, Staiger CJ, Grinstein S, et al (2013) Bem3, a Cdc42 GTPase-activating protein, traffics to an intracellular compartment and recruits the secretory Rab GTPase Sec4 to endomembranes. J Cell Sci 126: 4560-4571. doi:10.1242/jcs.117663

Neller J, Dunkler A, Rosler R, Johnsson N (2015) A protein complex containing Epo1p anchors the cortical endoplasmic reticulum to the yeast bud tip. J Cell Biol 208: 71-87. doi:10.1083/jcb.201407126

Okada S, Leda M, Hanna J, Savage NS, Bi E, Goryachev AB (2013) Daughter cell identity emerges from the interplay of cdc42, septins, and exocytosis. Dev Cell 26: 148-161. doi:10.1016/j.devcel.2013.06.015

Onishi M, Ko N, Nishihama R, Pringle JR (2013) Distinct roles of Rho1, Cdc42, and Cyk3 in septum formation and abscission during yeast cytokinesis. J Cell Biol 202: 311-329. doi:10.1083/jcb.201302001

Orlando K, Zhang J, Zhang X, Yue P, Chiang T, Bi E, Guo W (2008) Regulation of Gic2 localization and function by phosphatidylinositol 4,5bisphosphate during the establishment of cell polarity in budding yeast. J Biol Chem 283: 14205-14212. doi:10.1074/jbc.m708178200

Peter M, Neiman AM, Park HO, van Lohuizen M, Herskowitz I (1996) Functional analysis of the interaction between the small GTP binding protein Cdc42 and the Ste20 protein kinase in yeast. EMBO J 15: 7046-7059. doi:10.1002/j.1460-2075.1996.tb01096.x

Peterson J, Zheng Y, Bender L, Myers A, Cerione R, Bender A (1994) Interactions between the bud emergence proteins Bem1p and Bem2p and Rho-type GTPases in yeast. J Cell Biol 127: 1395-1406. doi:10.1083/jcb.127.5.1395

Phair RD, Scaffidi P, Elbi C, Vecerova J, Dey A, Ozato K, Brown DT, Hager G, Bustin M, Misteli T (2004) Global nature of dynamic protein-chromatin interactions in vivo: Three-dimensional genome scanning and dynamic interaction networks of chromatin proteins. Mol Cell Biol 24: 6393-6402. doi:10.1128/mcb.24.14.6393-6402.2004

Pruyne D, Legesse-Miller A, Gao L, Dong Y, Bretscher A (2004) Mechanisms of polarized growth and organelle segregation in yeast. Annu Rev Cell Dev Biol 20: 559-591. doi:10.1146/annurev.cellbio.20.010403.103108

R Core Team (2019) R: A Language and Environment for Statistical Computing. R Foundation for Statistical Computing. Vienna, Austria: R Core Team. Available at https://www.R-project.org/.

Rapali P, Mitteau R, Braun C, Massoni-Laporte A, Unlu C, Bataille L, Arramon FS, Gygi SP, McCusker D (2017) Scaffold-mediated gating of Cdc42 signalling flux. Elife 6: e25257. doi:10.7554/eLife.25257

Schaub Y, Dunkler A, Walther A, Wendland J (2006) New pFA-cassettes for PCR-based gene manipulation in Candida albicans. J Basic Microbiol 46: 416-429. doi:10.1002/jobm.200510133
Schneider C, Grois J, Renz C, Gronemeyer T, Johnsson N (2013) Septin rings act as a template for myosin higher-order structures and inhibit redundant polarity establishment. J Cell Sci 126: 3390-3400. doi:10.1242/jcs.125302

Shimada Y, Wiget P, Gulli MP, Bi E, Peter M (2004) The nucleotide exchange factor Cdc24p may be regulated by auto-inhibition. EMBO J 23: 1051-1062. doi:10.1038/sj.emboj.7600124

Sikorski RS, Hieter P (1989) A system of shuttle vectors and yeast host strains designed for efficient manipulation of DNA in Saccharomyces cerevisiae. Genetics 122: 19-27.

Smith GR, Givan SA, Cullen P, Sprague GF Jr. (2002) GTPase-activating proteins for Cdc42. Eukaryot Cell 1: 469-480. doi:10.1128/ec.1.3.469-480.2002

Smith SE, Rubinstein B, Mendes Pinto I, Slaughter BD, Unruh JR, Li R (2013) Independence of symmetry breaking on Bem1-mediated autocatalytic activation of Cdc42. J Cell Biol 202: 1091-1106. doi:10.1083/jcb.201304180

Takaku T, Ogura K, Kumeta H, Yoshida N, Inagaki F (2010) Solution structure of a novel Cdc42 binding module of Bem1 and its interaction with Ste20 and Cdc42. J Biol Chem 285: 19346-19353. doi:10.1074/jbc.m110.116749

Tanaka K, Tatebayashi K, Nishimura A, Yamamoto K, Yang HY, Saito H (2014) Yeast osmosensors Hkr1 and Msb2 activate the Hog1 MAPK cascade by different mechanisms. Sci Signal 7: ra21. doi:10.1126/scisignal.2004780

Tian C, Wu Y, Johnsson N (2014) Stepwise and cooperative assembly of a cytokinetic core complex in Saccharomyces cerevisiae. J Cell Sci 127: 3614-3624. doi:10.1242/jcs.153429

Tonikian R, Xin X, Toret CP, Gfeller D, Landgraf C, Panni S, Paoluzi S, Castagnoli L, Currell B, Seshagiri S, et al (2009) Bayesian modeling of the yeast SH3 domain interactome predicts spatiotemporal dynamics of endocytosis proteins. PLOS Biol 7: e1000218. doi:10.1371/journal.pbio.1000218

Tu D, Graziano BR, Park E, Zheng W, Li Y, Goode BL, Eck MJ (2012) Structure of the formin-interaction domain of the actin nucleation-promoting factor Bud6. Proc Natl Acad Sci U S A 109: E3424-E3433. doi:10.1073/ pnas.1203035109

Weiss EL, Bishop AC, Shokat KM, Drubin DG (2000) Chemical genetic analysis of the budding-yeast p21-activated kinase Cla4p. Nat Cell Biol 2 677-685. doi:10.1038/35036300

Wild AC, Yu JW, Lemmon MA, Blumer KJ (2004) The p21-activated protein kinase-related kinase Cla4 is a coincidence detector of signaling by Cdc42 and phosphatidylinositol 4-phosphate. J Biol Chem 279: 17101-17110. doi:10.1074/jbc.m314035200

Winters MJ, Pryciak PM (2005) Interaction with the SH3 domain protein Bem1 regulates signaling by the Saccharomyces cerevisiae p21-activated kinase Ste20. Mol Cell Biol 25: 2177-2190. doi:10.1128/mcb.25.6.2177-2190.2005

Witte K, Strickland D, Glotzer M (2017) Cell cycle entry triggers a switch between two modes of $\mathrm{Cdc42}$ activation during yeast polarization Elife 6: e26722. doi:10.7554/eLife.26722

Wittke S, Lewke N, Muller S, Johnsson N (1999) Probing the molecular environment of membrane proteins in vivo. Mol Biol Cell 10: 2519-2530. doi:10.1091/mbc.10.8.2519

Woods B, Kuo CC, Wu CF, Zyla TR, Lew DJ (2015) Polarity establishment requires localized activation of Cdc42. I Cell Biol 211: 19-26. doi:10.1083/jcb.201506108

Yamaguchi Y, Ota K, Ito T (2007) A novel Cdc42-interacting domain of the yeast polarity establishment protein Bem1. Implications for modulation of mating pheromone signaling. J Biol Chem 282: 29-38. doi:10.1074/jbc.m609308200

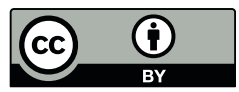

License: This article is available under a Creative Commons License (Attribution 4.0 International, as described at https://creativecommons.org/ licenses/by/4.0/). 